\title{
Las eVidencias arqueológicas de ÉPOCA Calcolítica del CerRo del Castillo de Medellín (Badajoz): el sondeo G'
} Chalcolithic archaeological evidences in Cerro del Castillo de Medellín (Badajoz, Spain): sondage ' $G$ '

ESTHER RODRÍGUEZ GoNZÁLEZ CSIC - Junta de Extremadura Eva REDONDo GómeZ María Martín Becerril Arqueólogas SAnTiago GuerRa MilláN Junta de Extremadura

Recibido: 08/03/2017

Revisado: $17 / 04 / 2017$
Aceptado: $19 / 05 / 2017$

Publicado: 23/06/2017

\section{RESUMEN}

Este trabajo recoge las evidencias materiales de época calcolítica documentadas en las diferentes intervenciones arqueológicas llevadas a cabo en las laderas del cerro del Castillo de Medellín (Badajoz). La aparición de varias estructuras y un significativo lote de materiales cerámicos, avalan la existencia de un momento de ocupación de este estratégico punto del valle medio del Guadiana durante el III Milenio a.C., lo que suma un punto más en el dinámico paisaje del poblamiento calcolítico de este territorio.
Palabras Clave

Calcolítico; Valle medio del Guadiana; asentamiento; estructura de combustión.
ABSTRACT

This work presents material evidence from Chalcolithic times documented through the different archaeological interventions undertaken on the side of the hill upon which the Medellín Castle stands (Badajoz). The appearance of different structures and a significant lot of ceramic materials support the existence of a moment at which this strategic point in the Middle Valley of the Guadiana River was occupied during the third millennium $\mathrm{BC}$ - a fact which is yet another important point to be studied in terms of the dynamic panorama of Chalcolithic settlement in this area.

\section{KEY WORDS}

Chalcolithic, Middle Valley of the Guadiana River, settlement, combustion structure.

esther.rodriguez@iam.csic.es 


\section{INTRODUCCIÓN}

El Calcolítico es posiblemente una de las etapas históricas mejor documentadas en el valle medio del Guadiana, de ahí que sea considerada como "la primera gran ocupación estable de este territorio" (Enríquez Navascués, 1995, 25). Esto se debe al aumento de población y de los asentamientos que se detecta en los inicios del III Milenio a.C., un aumento demográfico que se hizo notar, fundamentalmente, en el tramo medio del Guadiana (Hurtado Pérez, 1995, 59). La causa de ello son las excelentes condiciones naturales que reúne este espacio, apto para el desarrollo de la agricultura al tratarse de un paisaje dominado por las fértiles vegas del río Guadiana. A esto se suma la existencia de una suave orografía sin grandes elevaciones, un hecho que favorecería la comunicación por tierra; pero también a la calma que caracteriza a este tramo del cauce del Guadiana, lo que permitiría una fácil conexión entre los distintos asentamientos que se disponen junto a sus orillas o a las de sus principales afluentes. De ese modo, la permeabilidad del paisaje y su aptitud para el desarrollo de la agricultura han sido las razones principales para determinar la idoneidad de este espacio frente a otros paisajes donde la ocupación durante el Calcolítico presenta una fuerte dispersión (Heras Mora y Cerrillo Cuenca, 2006).

A la densidad de enclaves se suma el hecho de que el valle medio del Guadiana es una de las regiones mejor conocidas del mediodía peninsular como consecuencia de los innumerables trabajos arqueológicos que se han llevado a cabo en el mismo. Las primeras investigaciones a este respecto fueron efectuadas en los años 90 por J. J. Enríquez Navascués, cuyos resultados quedaron recopilados en un trabajo sobre el Calcolítico en Extremadura (1990), el cual todavía constituye un referente para el estudio de esta fase histórica. En este trabajo el volumen de enclaves detectados ya era notable (Enríquez Navascués, 1990, 35); sin embargo, desde su publicación el número de hallazgos y la naturaleza y tipología de los mismos no han dejado de aumentar (Heras y Cerrillo, 2006). Esto se debe, fundamentalmente, a las arduas tareas de prospección que se han llevado a cabo en torno a la cuenca media del Guadiana, tanto en la comarca de Mérida (Enríquez, 2003) como en los alrededores del municipio de Medellín (Rodríguez Díaz et alii, 2009; Sevillano Perea et alii, 2013), espacio objeto de estudio en este trabajo.
El excelente conocimiento del territorio que comprende el valle medio del Guadiana durante el Calcolítico ha llevado a localizar un destacado número de asentamientos, lo que ha permitido establecer una jerarquía de los mismos que se diferencia por la ubicación que el enclave ocupa en el paisaje, pues su tamaño, disposición y funcionalidad varían en la gran mayoría de los casos conocidos. Este hecho dota de gran homogeneidad y diversidad al poblamiento de este período y de este territorio. A rasgos generales se han establecido cuatro categorías distintas dentro de este mismo espacio (Enríquez Navascués, 1995, 26; Rodríguez Díaz y Enríquez Navascués, 2001, 63). El primer grupo incluye los asentamientos en llano, de fuerte vocación agrícola $\mathrm{y}$ con una funcionalidad complementaria con respecto a los enclaves mayores; una segunda categoría agrupa a los poblados localizados sobre suaves lomas o pequeñas elevaciones; en el tercer grupo se incluirían los enclaves ubicados sobre cerros dominantes con clara finalidad estratégica, pues habitualmente ocupan un espacio próximo al vado del río; y, por último, la cuarta categoría se reserva para los poblados fortificados. Dentro de este último grupo se encuentran los asentamientos de Palacio Quemado (Hurtado Pérez y Enríquez Navascués, 1991) o La Palacina (Enríquez Navascués, 1990), ambos en el término municipal de Alange. El tamaño de estos enclaves y la presencia de elementos defensivos en su estructura, hacen que sean considerados como las cabezas para el control del tramo más oriental del cauce medio del Guadiana.

Por su parte, el enclave documentado en las excavaciones de Medellín (fig. 1) que a continuación abordaremos, parece pertenecer a esta segunda categoría de asentamiento. A pesar de que el cerro del Castillo de Medellín es uno de los puntos más estratégicos del paisaje de la cuenca media del Guadiana al ubicarse en uno de los vados del río, justo en la confluencia entre los ríos Ortiga y Guadiana (fig.2), el enclave de Medellín parece localizarse a media ladera en la cara del cerro, espacio en el que se concentran todas las evidencias documentadas. Su posición a media ladera reduce la visibilidad de éste con respecto a su entorno, a pesar de que desde el cerro del Castillo de Medellín se posee un fuerte control visual del mismo. Frente a ello, la ubicación del asentamiento en este punto le permite tener un control más directo sobre la vega del río y su explotación agrícola. 


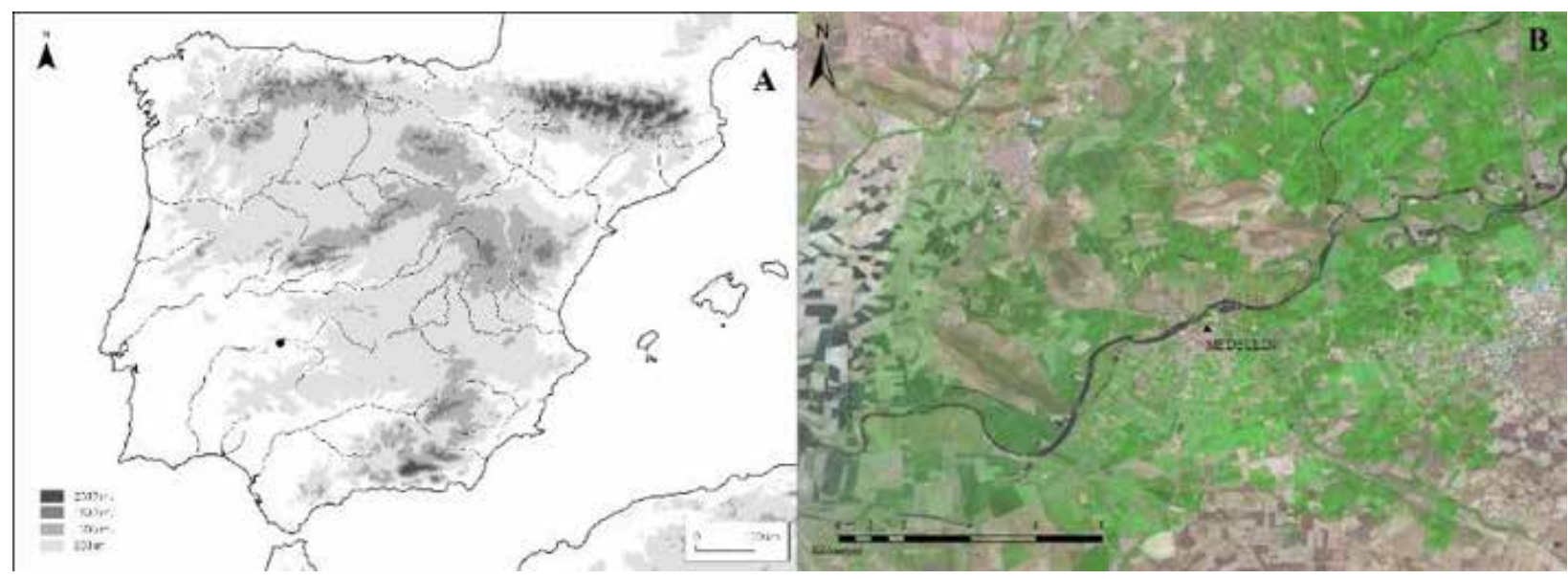

Figura 1

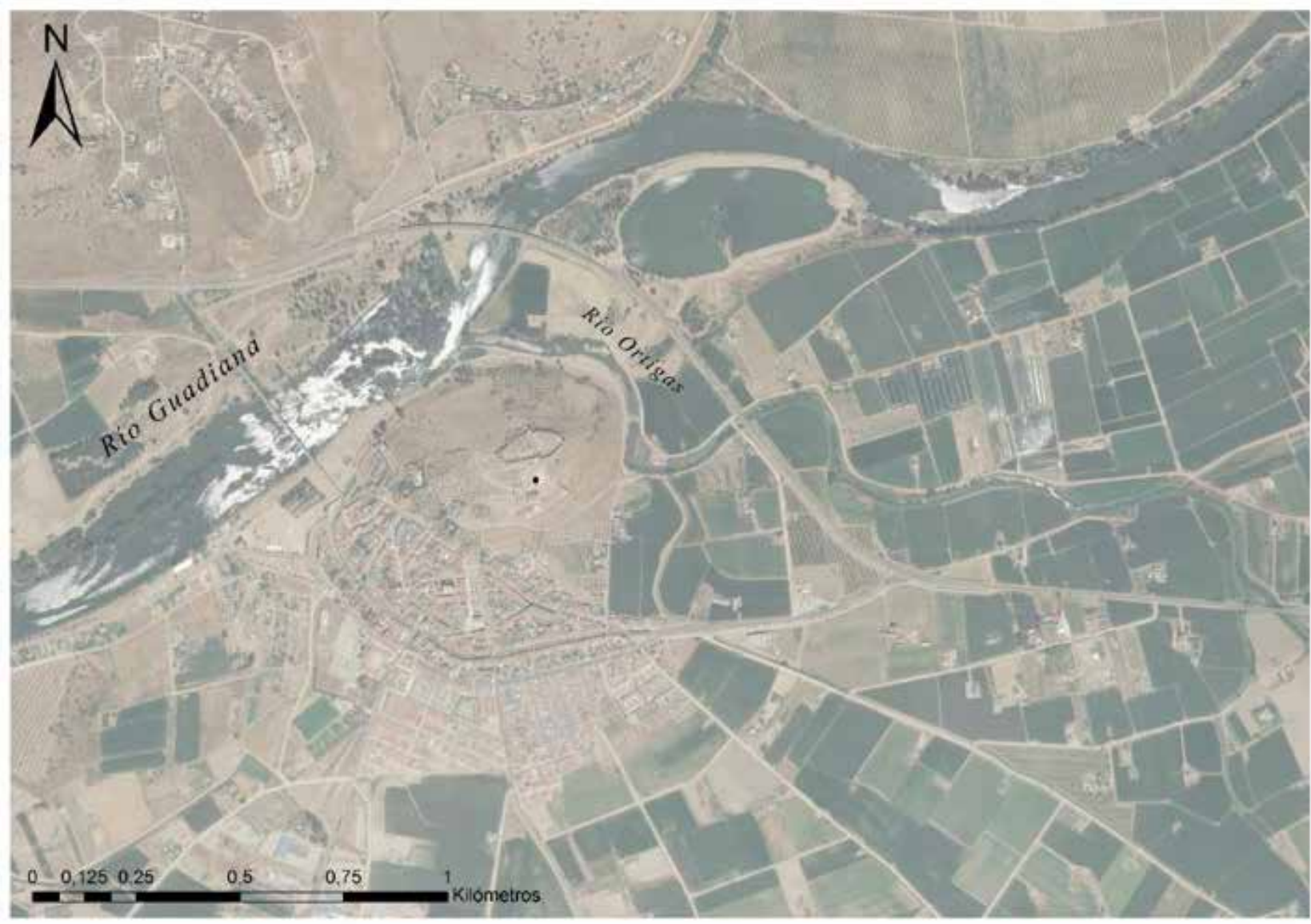

Figura 2

2. La ocupación CALColítica de Medellín

La existencia de una fase de ocupación del cerro del Castillo de Medellín durante el Calcolítico era hasta hace pocos años desconocida (Jiménez Ávila y Guerra Millán, 2012, 76); sin embargo, la presencia de un enclave de esa cronología en este estratégico punto del paisaje no es de extrañar, dado que se trata de un patrón que se repite a lo largo de toda la cuenca del Guadiana, donde los vados de los ríos habitualmente cuentan con poblados calcolíticos en sus proximidades (Enríquez Navascués, 2003, 79), y Medellín no constituye una excepción a este modelo. La primera evidencia que dejó constancia de la existencia de un posible momento de ocupación del 
cerro del Castillo de Medellín durante el III milenio a.C. aparece recogida en un trabajo cuyo objetivo era el estudio preliminar del Corte Sector Muralla Romana Occidental (SMRO); un sondeo localizado en la ladera occidental de la elevación en el que habían sido documentados unos niveles de ocupación del Bronce Final (Jiménez Ávila y Guerra Millán, 2012). Entre los materiales cerámicos recuperados del corte estratigráfico se localizaron varios fragmentos de perfil abierto y borde engrosado que por su tipología parecían corresponder con los típicos perfiles del Calcolítico del mediodía peninsular; sin embargo, estas piezas de cerámica estaban fuera de contexto, pues no se documentaron niveles estratigráficos que permitieran asegurar la existencia de una ocupación calcolítica en este punto de la elevación, aunque sí suponerla. Así mismo, dentro de este trabajo se recoge una referencia a la aparición de un silo de posible cronología calcolítica, cortado por los cimientos del teatro romano, que fue excavado durante la campaña de 2007 (Jiménez Ávila y Guerra Millán, 2012, 94). Los materiales recuperados durante la excavación de la mencionada estructura forman parte de este trabajo, junto con las evidencias extraídas del denominado sondeo 'G', también efectuado en un sector del graderío del teatro romano aprovechando un punto en el que los sillares que lo componen habían sido expoliados. La finalidad de este estudio no es otra que la de recoger las evidencias de la Edad del Cobre documentadas en Medellín, añadiendo con ello un punto más en el mapa del poblamiento de este interesante período (fig. 3).

\subsection{EL SONDEO ' $G$ '}

La excavación del sondeo 'G' se llevó a cabo dentro de los trabajos integrados en el Proyecto de "Recuperación y Puesta en Valor del Teatro Romano de Medellín”, ejecutado por la Junta de Extremadura en convenio con la Mancomunidad Integral de $\mathrm{Mu}-$ nicipios del Guadiana en los años 2009 y 2010. Este proyecto tenía como objetivo la intervención en el teatro romano para dejar visto y visitable el edificio, dando como resultado una interesante lectura

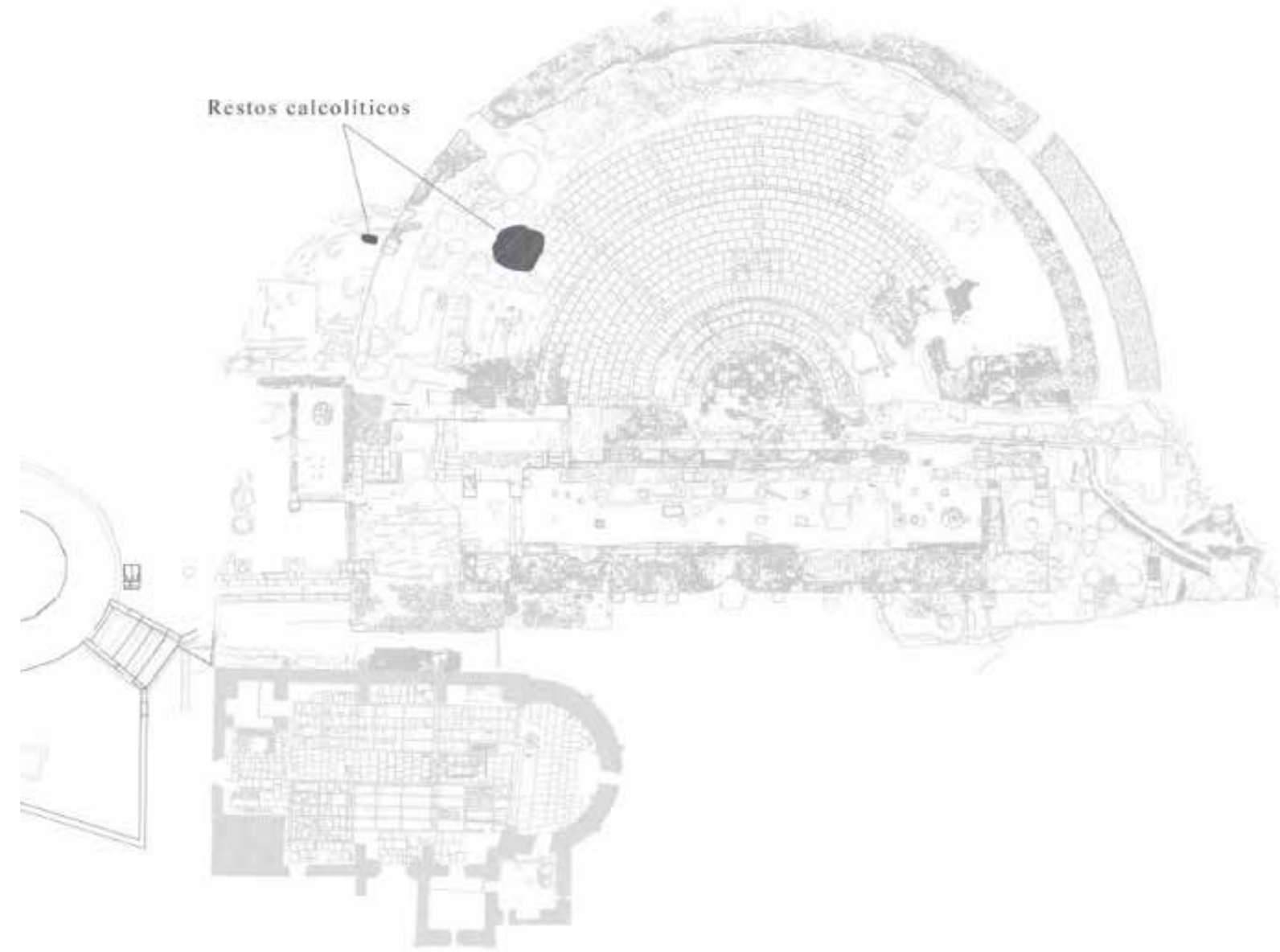

Figura 3 


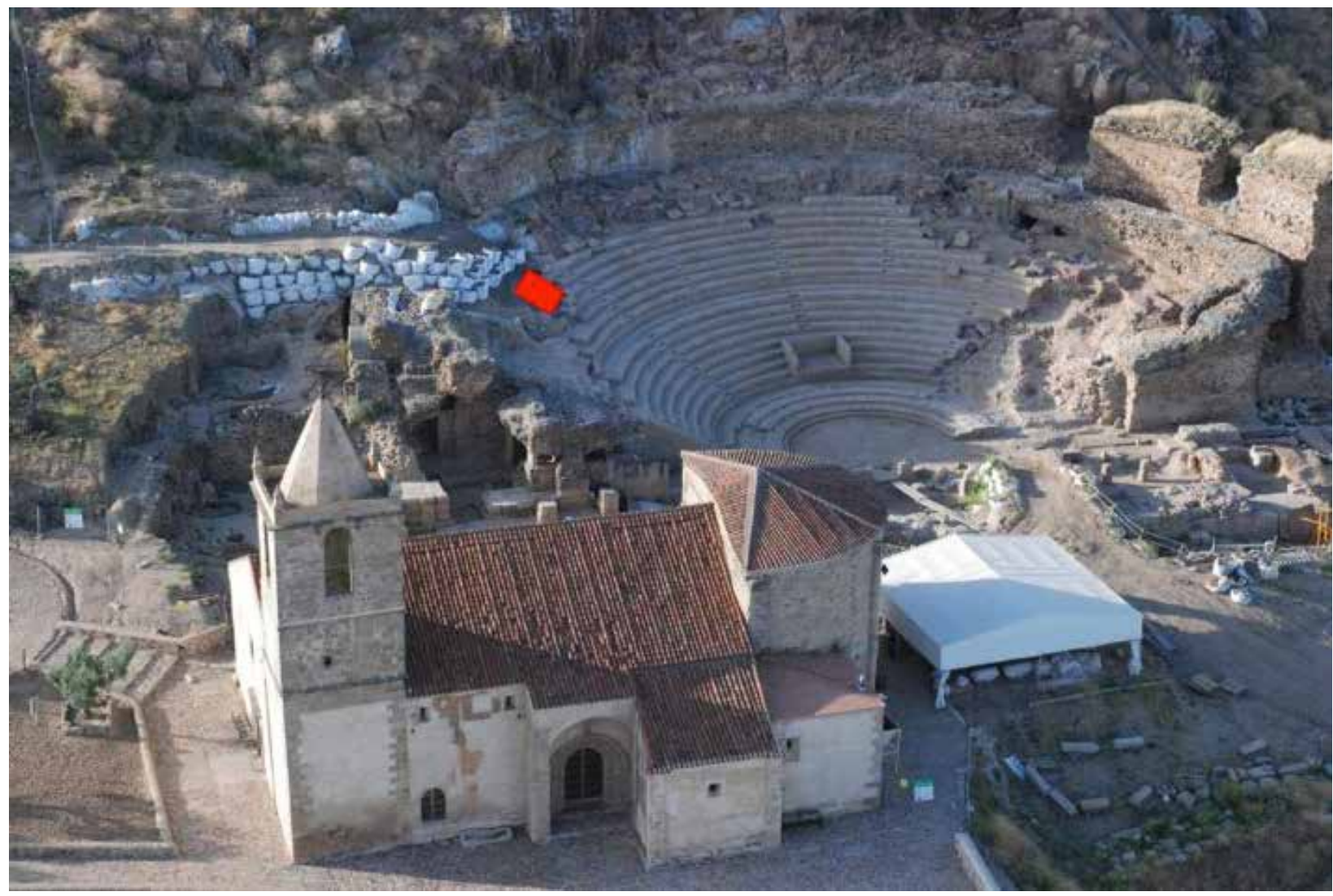

Figura 4

tanto estratigráfica como materiales de las ocupaciones anteriores y posteriores a la construcción del mismo. Así pues, en toda la superficie ocupada por el teatro, se documentaron, en primer lugar, un conjunto de habitaciones y un camino que durante época moderna y contemporánea ocuparon y alteraron la estructura romana. Por debajo de esos niveles modernos se excavaron habitaciones y silos de época emiral, califal y almohade que habían arrasado parte del teatro y la estratigrafía previa a su construcción. De ese modo, aprovechando el expolio de un conjunto de sillares en la zona oeste del graderío, se programó la ejecución del sondeo ' $G$ ', cuyos resultados se muestran a continuación y cuyo objetivo era confirmar si existía ocupación anterior a la construcción del teatro y cómo la ejecución de éste había afectado a los niveles estratigráficos conservados.

El sondeo ' $G$ ' se sitúa a media ladera del cerro del Castillo de Medellín (fig. 4), en una zona escarpada. Delimita al norte y al este con las gradas del teatro, mientras que al oeste y al sur sus límites los marcan varios silos islámicos y estratos horizontales. $\mathrm{Al} \mathrm{co-}$ mienzo de los trabajos el sondeo contaba con unas dimensiones de 2,60 de largo x 1,75 de ancho; sin embargo, los interesantes hallazgos motivaron su ampliación tanto por el sur como por el este. En cuanto a la profundidad, se alcanzaron los $2 \mathrm{~m}$ con respecto a la cota inicial y, aunque no se agotó la potencia estratigráfica, hubo que detener los trabajos por cuestiones de seguridad. Por último, la metodología empleada en la excavación siguió el sistema de registro Harris, identificándose 67 unidades estratigráficas interpretadas en contextos funcionales. A continuación se presenta la secuencia de excavación documentada en la que se diferencian dos momentos de ocupación, un primero hispanorromano y uno anterior de época calcolítica.

\subsubsection{DESCRIPCIÓN DE LAS UNIDADES ESTRATIGRÁFI-} CAS DOCUMENTADAS EN EL SONDEO 'G'.

Dos silos 6487 y 6494 islámicos situados en el lado este y sur del sondeo, han cortado prácticamente todos los niveles de la excavación del mismo.

UEs 6579, 7817 y 7818: Nivelación. Romano. Estratos de composición, compactación y textura 
variada. Ocupan en extensión toda la zona desde el corredor hasta las gradas conservadas. Alterados por múltiples silos islámicos, rellenan y nivelan los cortes escalonados que se ejecutaron para encajar las gradas.

Relaciones estratigráficas: Cubierto por UE 7819. Rellena a UE 7815.

UE 7815: Corte escalonado. Romano. Corte escalonado para encajar los sillares del graderío.

Relaciones estratigráficas: Relleno por UEs 6579, 7817 y 7818. Corta a UE 7820.

UE 7819: Nivelación. Romano. Estrato de tierra arcillosa compacta, cubierto por una fina capa de arenas sobre la que se asientan directamente los sillares.

Relaciones estratigráficas: Cubierto por sillares que forman las gradas UEs 4002, 4003, $4004 \mathrm{y}$ 4005. Cubre a UEs 6579, 7817 y 7818.

UE 7820: Nivel de colmatación. Ocupación D. Estrato de cenizas heterogéneas con buzamiento norte-sur.

Relaciones estratigráficas: Cubierto por UE 7818. Cubre a UE 7821. Cortado por UE 7815.

UE 7821: Nivel de colmatación. Ocupación D. Estrato de tierra arenosa de grano grueso, color rojizo con vetas de cenizas grises que buza en sentido norte-sur. En el extremo sur del sondeo presencia de piedras de cuarcita de tamaño medio.

Relaciones estratigráficas: Cubierto por UE 7820. Cubre a UE 7822. En relación con UE 7847.

UE 7822: Posible nivel de incendio. Ocupación D. Estrato compuesto por cenizas de color negro de mayor potencia en la zona norte del sondeo que en la zona sur Relaciones estratigráficas: Cubierto por UE 7821. Cubre a UEs 7823 y 7824. Igual a UE 7851.

UE 7823: Estrato de abandono. Ocupación D. Estrato compuesto por cenizas de color ocre que se distribuye de forma uniforme por todo el sondeo, cubriendo al nivel de uso de la Ocupación D.

Relaciones estratigráficas: Cubierto por UE 7822. Cubre a UEs 7827-7829-7854-7852 y 78437844. Se adosa a UE 7845.

UE 7824-7845: Agujero de poste y su relleno. Ocupación D. Fosa de pequeñas dimensiones con un diámetro de 0.18 y profundidad $0.22 \mathrm{~m}$. Localizado junto al perfil norte, relleno por resto del poste descompuesto/carbonizado (UE 7845).

Relaciones estratigráficas: Cubierto por UE 7822. Corta a UE 7827, 7830, 7833, 7835 y 7836. Se le adosa UE 7823.
UE 7825: Nivel de abandono. Momento C3. Estrato de cenizas grises limosas mezcladas con granos de arcilla anaranjada, amarillenta y marrón por exposición al fuego. Localizado en el interior de la Estructura de combustión C3.

Relaciones estratigráficas: Cubierto por UEs 7827-7829. Cubre a UE 7855. Se adosa a UE 7837.

UEs 7827-7854-7852-7829: Suelo. Ocupación

D. Estratos de composición arenosa, muy compactos, de color verdoso en el que se han utilizado piedras muy pequeñas mezcladas con arcilla y con cerámica para conseguir una alta compactación. De unos 3 / 4 cm de espesor. UEs 7827 y 7854 al exterior de la estructura circular y UEs 7852 y 7829 al interior.

Relaciones estratigráficas: Cubierto por UE 7823. Cubre a UEs 7825, 7837-7838, 7853, 7855. Cortada por UEs 7824 y 7843.

UE 7828: Estructura de combustión C1. Momento C1. Estructura excavada en estratos de nivelación con restos de rubefacción en la base y rematada con una moldura de arcilla de forma circular abierta en su lado sureste, con un diámetro máximo de $1 \mathrm{~m}$.

Relaciones estratigráficas: Cubierto por UEs 7833 y 7874 , se le apoya y adosa UEs 7837, 78587846. Se le adosa al exterior UEs 7835, 7874 y 7923. Se le adosa al interior UEs 7831, 7834 y 7840-7860. Corta y cubre a UEs 7924 y 7926.

UE 7830: Nivel de abandono. Momento C3. Estrato compuesto por cenizas negras poco compactas de escaso espesor, poco homogéneas.

Relaciones estratigráficas: Cubierto por UE 7853. Cubre a UEs 7833 y 7832-7856-7857-7878. Se adosa a UEs 7837 y 7858. En relación con UE 7855. Cortado por UE 7824.

UE 7831: Solera estructura de combustión C3. Momento C3. Estrato de arcillas rosas muy limpias sobre las que se apoya la reforma UE 7837 en el interior de la estructura de combustión.

Relaciones estratigráficas: Cubierto por UE 7855. Se le apoya UE 7837. Cubre a UE 7834. Se adosa a UEs 7828 y 7846 .

UEs 7832-7856-7857-7878: Agujeros de poste. Momento C3. Subestructuras que cortan al nivel UE 7833. Son de planta circular, unos $7 \mathrm{~cm}$ de diámetro y $7 \mathrm{~cm}$ de profundidad con la pared quemada y relleno de cenizas. La falta de espacio en el sondeo no permite concretar finalidad.

Relaciones estratigráficas: Cubierto por UE 7830. Corta a UEs 7833 y 7835. 
UE 7833: Suelo. Momento C3. Estrato de arcillas niveladas sobre la que colocan una fina capa de cal homogénea que cubre a la estructura de combustión UE 7828 en su totalidad. Se conserva bien en la zona este y norte de la estructura circular, cubriendo parcialmente a la estructura 7837 y ajustándose al volumen de 7828. Al sur de la estructura, este estrato aparece en calvas.

Relaciones estratigráficas: Cubierto por UE 7830. Cubre a UEs 7828, 7835, 7872, 7873 y 7874. Cortado por UEs 7824, 7832-7856-7857-7878. Se adosa a UE 7837.

UE 7834: Solera de la estructura de combustión C2. Momento C2. Estrato de arcillas compactadas que ocupan de forma horizontal el interior de la estructura, creando una superficie rubefactada.

Relaciones estratigráficas: Cubierto por UE 7831. Cubre a UEs 7840-7860. Se adosa a UE 7828. En relación directa con UEs 7858-7846.

UE 7835: Nivel de uso. Momento C2. Estrato compuesto a base de piedras muy pequeñas mezcladas con arenas gruesas y arcillas blanquecinas y anaranjadas y grisáceas. Se localiza en la zona norte del sondeo en el extremo más próximo al perfil norte continuando por debajo de éste y del perfil este.

Relaciones estratigráficas: Cubierto por UE 7833. Cubre a UE 7923. Se adosa a UE 7828. Cortado por UEs 7824, 7832-7856-7857-7878.

UE 7836: Vertido. Estrato arcilloso anaranjado que buza siguiendo la pendiente de la ladera al igual que les ocurre a los estratos UEs 7936, 7938 y 7939.

Relaciones estratigráficas: Cubierto por UEs 7926, 7933, 7934. Cubre a UE 7936. Cortado por UEs 7824 y 7937 . Igual a UE 7839.

UEs 7837-7838: Estructura de combustión C3. Momento C3. Estructura tipo hogar de sección ovalada y forma en planta semicircular. La UE 7837 cerraría la estructura en su zona norte a base de granito disgregado que da una consistencia muy compacta. Se observa que su mitad sur se encuentra en peor estado y que ha sufrido más remodelaciones (UE 7838) con el mismo tipo de materiales, granito disgregado compactado. Las UEs 7837 y 7838 se aprovechan de una reforma anterior para cerrar la estructura en su lado sur.

Relaciones estratigráficas: La UE 7837 está cubierta por UEs 7827-7829 y se apoya en UEs 7828-7858-7846, 7831. La UE 7838 está cubierta por UEs 7827, se apoya en UE 7874 y cortado por UE 6494. Se les adosa al interior las UEs 7825 y 7855 (esta última se extiende cubriendo parcial- mente a UE 7838) y al exterior UEs 7830, 7833 y 7853.

UE 7839: Vertido.

Relaciones estratigráficas: Igual a UE 7836.

UEs 7840-7860: Niveles de colmatación de la estructura de combustión C1 UE 7828. Momento C1. Estratos de arenas marrones mezcladas con arcillas con presencia frecuente de piedras de cuarcita de pequeño tamaño.

Relaciones estratigráficas: Cubierto por UE 7834. A la UE 7860 se le apoya 7858. Se adosa a UE 7828.

UEs 7843-7844: Fosa y su colmatación. Momento D. UEs que se corresponden con lo que parece una fosa delimitado su contorno por piedras de cuarcita de tamaño medio, colmatada por un nivel de cenizas mezcladas con piedras pequeñas. No se ha excavado en su totalidad porque continúa por debajo del perfil de la excavación.

Relaciones estratigráficas: Cubierto por UE 7823. Corta a UEs 7827.

UE 7847: Nivel de colmatación. Ocupación D. Estrato de tierra arenosa de grano grueso, mezclado con granito disgregado. Documentado en la esquina noreste del sondeo, continúa fuera de los límites del sondeo, por los perfiles norte y este.

Relaciones estratigráficas: En relación con UE 7821.

UE 7851: Posible nivel de incendio. Ocupación D. Estrato compuesto por cenizas de color negro.

Relaciones estratigráficas: Igual a UE 7822.

UE 7852: Piedras colocadas en círculo. Ocupación D. Estructura formada por una alineación de piedras colocadas en círculo en cuyo interior se le dio la UE 7929 pero su naturaleza era igual que el estrato UE 7827 que rodeaba estas piedras.

Relaciones estratigráficas: Cubierto por UE 7823. Cubre a UE 7827.

UE 7853: Estrato de nivelación. Ocupación D. Estrato de composición arcillosa-cenicienta, de color claro con pegotes de arcillas anaranjadas. Localizado en la mitad norte del sondeo y por debajo del nivel de uso UEs 7827-7829.

Relaciones estratigráficas: Cubierto por UEs 7827 y 7854. Cubre a UE 7830. Se adosa a UE 7837.

UE 7855: Nivel de abandono. Momento C3. Estrato de cenizas negras de escaso espesor documentado en el interior de la estructura extendiéndose hacia el sur. 
Relaciones estratigráficas: Cubierto por UEs 7825 y 7827 . Cubre a UEs 7831, 7838, 7858-7846. Se adosa a UE 7837. En relación con UE 7830.

UEs 7858-7846-7828: Reforma de estructura, formando la Estructura de combustión C2. Momento C2. La estructura circular de inicio UE 7828 estaba abierta en la parte sur, en este momento se cierra con esta reforma UE 7858, construida a base de granito disgregado mezclado con arcillas muy compactadas. Al interior de la estructura colocan adobes (UE 7846) que servirían de parapeto para el fuego, irían en relación con la solera UE 7834 .

Relaciones estratigráficas: Las UEs 7858-7846 se adosan a UE 7828, están cubiertas por UE 7855, se apoyan en UE 7860 y están en relación directa con la solera UE 7834. A la UE 7858 se le adosan al exterior las UEs 7830 y 7872 e iría en relación con UE 7876. Se le apoya UE 7837. Cubre a UE 7879. A la UE 7846 se le adosa la UE 7831.

UE 7872: Estrato de regularización que sella fosa. Momento C3. Concentración de arcillas de color verde localizadas al exterior de la estructura C3 en su lado sur, sellando una fosa anterior y regularizando para uso posterior con el estrato UE 7833.

Relaciones estratigráficas: Cubierto por UE 7833. Cubre a UEs 7873, 7874, 7876-7877. Se adosa a UE 7858.

UE 7873: Nivelación y uso. Momento C2 y C1. Estrato de tierra de arcillas muy compactas de color amarillo, mezcladas con arenas de grano grueso dando mayor consistencia al estrato, localizadas en el extremo SE del sondeo. Se usa como Nivelación y uso en C2 junto con la UE 7874 y como regularización en C1 junto con la UE 7924.

Relaciones estratigráficas: Cubierto por UEs 7833, 7872, 7874 y 7923. Cubre a UEs 7924, 7925, 7927. Cortado por UE 7876.

UE 7874: Nivelación y uso. Momento C2. Estrato arcilloso-limoso que repara los desperfectos producidos en la estructura primigenia (UE 7828) cubriéndola parcialmente, regularizando la superficie para recibir la reforma (UEs 7858 y 7846). Localizado al sur de la estructura, se usa como nivelación y uso en C2 junto con la UE 7873.

Relaciones estratigráficas: Cubierto por UEs 7833 y 7872 . Se le apoya UE 7838. Cubre a UEs $7828,7873,7879,7923$ y 7924 . Se adosa a UE 7828. Cortado por UE 7876.

UEs 7876-7877: Cubeta y relleno de amortización. Momento C2. Subestructura de pequeñas dimensiones documentada junto a la estructura de combustión C2 rellena por cenizas negras mezcladas con carbones.

Relaciones estratigráficas: Cubierto por UE 7872. Corta a UEs 7873 y 7874. En relación con UE 7858.

UE 7879: Nivel de uso. Momento C1. Estrato de cenizas negras localizadas en el contorno exterior de la estructura de combustión C1 en su lado sur.

Relaciones estratigráficas: Cubierto por UEs 7858 y 7874 . Cubre a UE 7923.

UE 7923: Suelo de cal. Momento C1. Estrato de arcilla mezclada con cal, capa muy fina, mejor conservada al sur de la estructura de combustión y sobre los estratos UEs 7873, 7924.

Relaciones estratigráficas: Cubierto por UEs 7835, 7874, 7879. Cubre a UEs 7873, 7924 y 7926. Se adosa a UE 7828 .

UE 7924: Nivelación. Momento C1. Estrato de tierra de arcillas muy compactas de color amarillo, mezcladas con arenas de grano grueso dando mayor consistencia al estrato. Junto a la UE 7873, regularizan la superficie sobre la que se construye la estructura de combustión UE 7828 y reciben el suelo de cal (UE 7923)

Relaciones estratigráficas: Cubierto por UEs 7923, 7873 y 7874. Cubre a UEs 7925, 7926 y 7927. La fosa de la estructura de combustión C1 corta a este estrato y la moldura perimetral se apoya en el mismo.

UE 7925: Nivel de abandono. Ocupación B. Estrato de tierra limosa de color gris que se localiza en el lado este del sondeo y continúa por debajo el graderío, posiblemente se trate del momento de abandono del nivel de uso UE 7926.

Relaciones estratigráficas: Cubierto por UEs 7873 y 7924. Cubre a UEs 7926 y 7927.

UE 7926: Nivel de uso. Momento C1 y Ocupación B. Estrato de tierra arcillosa-arenosa de color rojizo y restos de lechada de cal dispersos por todo el estrato. Relaciones estratigráficas: Cubierto por UEs 7923, 7924, 7925 y 7927. Cubre a UEs 7836, 7933. La fosa de la estructura de combustión C1 corta a este estrato y la moldura perimetral se apoya en el mismo.

UE 7927: Posible derrumbe de estructura. Ocupación B. Acumulación de piedras de mediano y gran tamaño, mezcladas con arenas limpias, localizado en el lado Este del sondeo y continúa por debajo del graderío. Posible derrumbe de una estructura asociada al nivel de uso UE 7926. 
Relaciones estratigráficas: Cubierto por UEs 7873, 7924 y 7925. Cubre a UE 7926.

UE 7933: Nivel para regularizar superficie. Ocupación B. Estrato compuesto por granito disgregado mezclado con piedras de cuarcita.

Relaciones estratigráficas: Cubierto por UE 7926. Cubre a UEs 7836, 7934.

UE 7934: Aporte antrópico de piedras. Ocupación $\mathrm{B}$. Piedras de tamaño mediano y pequeño que aumentan su presencia, concentración y potencia hacia el sureste, colocadas para nivelar la superficie y conseguir una cota uniforme, sobre el que colocarán una capa de granito disgregado mezclado con arcilla que homogeniza la superficie UE 7933.

Relaciones estratigráficas: Cubierto por UE 7933. Cubre a UE 7836.

UE 7936: Vertido. Estrato anaranjado, compacto, con restos de cuarcitas mezcladas con arcillas que se distribuye buzando de noroeste a sureste.

Relaciones estratigráficas: Cubierto por UEs 7836. Cubre a UE 7938. Cortado por UE 7937.

UE 7937-7935: Madriguera y su relleno. Ha alterado varios estratos del sondeo.

Relaciones estratigráficas: Corta a UEs 7836, 7936, 7938 y 7939.

UE 7938: Vertido. Estrato arenoso-limoso de arenas muy finas y limpias de color verdoso que se localiza en la mitad este y que de la misma manera que el estrato anterior, buza hacia el sureste.

Relaciones estratigráficas: Cubierto por UE 7936. Cubre a UE 7939. Cortado por UE 7937.

UE 7939: Vertido. Estrato de arenas arcillosas de color rojizo con algunas piedras de mediano tamaño mezcladas con arcillas y arenas de grano más grueso y que ocupa prácticamente toda la planta excavada.

Relaciones estratigráficas: Cubierto por UE 7938. Cubre a UEs 7940, 7942 y 7954. Cortado por UE 7937.

UE 7940: Vertido. Estrato de arenas finas muy sueltas.

Relaciones estratigráficas: Cubierto por UE 7939. Cubre a UEs 7941 y parcialmente a 7942.

UE 7941: Posible derrumbe. Ocupación A. Bloques compactos de granito mezclados con arcillas, presentan caras planas y cubiertos con carbonatos.

Relaciones estratigráficas: Cubierto por UE 7940. Cubre a UE 7942. Rellena a UE 7954.

UE 7942: Nivel de colmatación de una posible cabaña. Ocupación A. Estrato de arcillas naranjas con pellas de granito.
Relaciones estratigráficas: Cubierto por UEs 7940 y 7941. Cubre a UE 7953. Rellena a UE 7954.

UE 7953: Nivel de abandono. Ocupación A. Estrato de limos de color verde que ocupa prácticamente toda la planta del sondeo.

Relaciones estratigráficas: Cubierto por UE 7942. Cubre a UE 7955. Rellena a UE 7954.

UE 7954: Posible cabaña. Ocupación A. Subestructura excavada en el geológico de granito y en otro estrato compacto (UE 7957). Presenta paredes inclinadas sin haber podido llegar a la base por lo que no se ha documentado la estructura en su totalidad.

Relaciones estratigráficas: Cubierto por UE 7939. Relleno por UEs 7941, 7942, 7953, 7955 y 7956. Corta a UE 7957 y al geológico.

UE 7955: Nivel de uso. Ocupación A. Capa de granito disgregado creando una superficie uniforme.

Relaciones estratigráficas: Cubierto por UE 7953. Cubre a UE 7956. Rellena a UE 7954.

UE 7956: Nivel de preparación. Ocupación A. Compuesto por arcillas naranjas bastante limpias que sólo se ha documentado en aquellas zonas donde la UE 7955 se había perdido. Se deja in situ.

Relaciones estratigráficas: Cubierto por UE 7955. Rellena a UE 7954.

UE 7957: Estrato formado posiblemente por la acción de agentes naturales que han provocado el desprendimiento de granito y cuarcita de la ladera, con el paso del tiempo se han compactado y en esta zona se ha cortado para construir la posible cabaña.

Relaciones estratigráficas: Cortado por UE 7954.

\subsubsection{SECUENCIA ESTRATIGRÁFICA CALCOLÍtica.}

Las unidades estratigráficas de época romana se corresponden con la construcción del graderío. Se trata de un corte escalonado que afecta a la estratigrafía previa y que ha sido practicado para encajar las gradas y los aportes de tierra (UEs 6579, $7817,7818)$ para nivelar y preparar el terreno para recibir los sillares. El sondeo dejó ver el esquema constructivo del graderío, documentando un corte escalonado (UE 7815) que afecta a la estratigrafía previa existente. Este corte se regulariza con una fina capa de arcillas y arenas (UE 7819) sobre la que fueron colocados los sillares. Como puede verse en el estudio que se recoge más adelante, los materiales recuperados de estos estratos corresponden tanto a cronología romana como prehistórica, ya que se trata de diferentes aportes de tierra. 
Tras la excavación de los niveles romanos, la continuación de la secuencia muestra el uso del espacio en varios momentos que pueden englobarse dentro de época calcolítica. La secuencia se inicia con una fosa habitacional sellada por niveles de arrastre o vertidos que son regularizados posteriormente para preparar un nuevo momento de uso con una estructura de combustión. Dicha estructura sufrió varias reformas y sus niveles de abandono fueron sellados por un último momento de vida cuya colmatación se vio afectada por la construcción del graderío.

Para comprender mejor la secuencia documentada, hemos dividido la estratigrafía en cuatro momentos de ocupación diferenciados pero comprendidos dentro de la misma etapa cronológica que serán presentados en el orden inverso a su documentación, es decir, partiendo de la descripción de los hallazgos más antiguos (fig. 5):

- Ocupación A: La más antigua con una estructura negativa de habitación de grandes dimensiones que podría funcionar como cabaña.

- Ocupación B: Regularización y nivel de uso.

- Ocupación C: Estructura de combustión y reformas (Momentos C1, C2 y C3)

- Ocupación D: Regularización y nivel de uso.
La ocupación A es la más antigua documentada en el sondeo. Está compuesta por una estructura negativa de habitación, un nivel de uso, su abandono y su posterior colmatación. Dicha estructura (UE 7954) se realizó practicado un corte en un nivel de granito rosa y cuarcitas al oeste del sondeo. Este nivel contiene grandes bloques de cuarcita (UE 7957) procedentes de los desprendimientos de la parte más elevada del cerro, por lo que su aparición dentro de la secuencia es un motivo recurrente como ya iremos viendo.

Aunque solo ha sido excavada una parte de la estructura, algo más al sur y fuera de los límites del sondeo, concretamente en el silo UE 6684, se documentó un corte de características similares, lo que plantea la hipótesis de que pudiera tratarse de la misma estructura negativa de grandes dimensiones que funcionalmente se usase como estructura de habitación tipo cabaña. Dicha estructura cuenta con un nivel de uso (UE 7955). Está formado por una capa de granito disgregado que ha sido colocado sobre un preparado de arcillas (UE 7956), lo que permite conseguir una superficie uniforme. De la UE 7956 únicamente podemos señalar que está compuesta de arcillas naranjas bastante limpias y
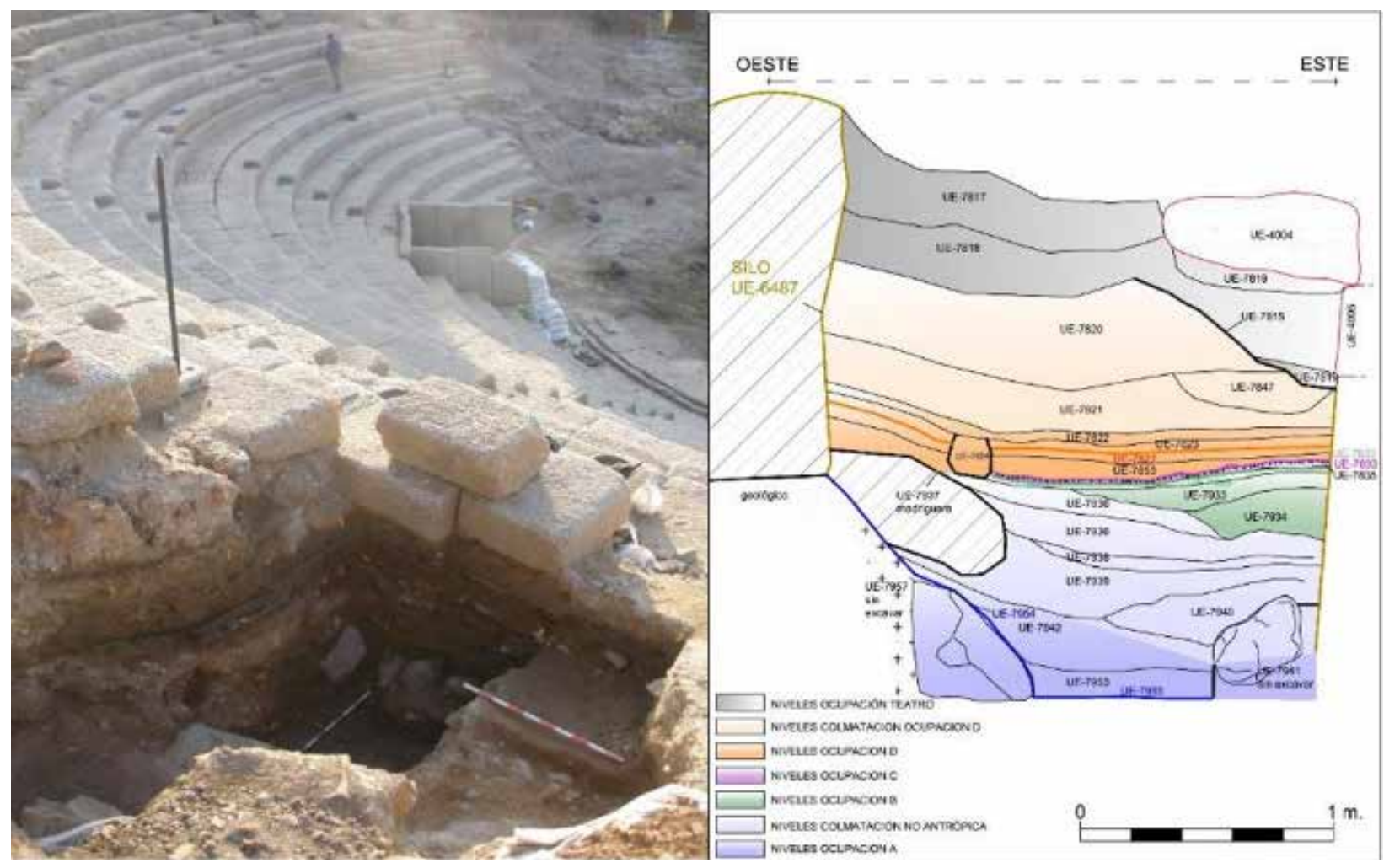

Figura 5 


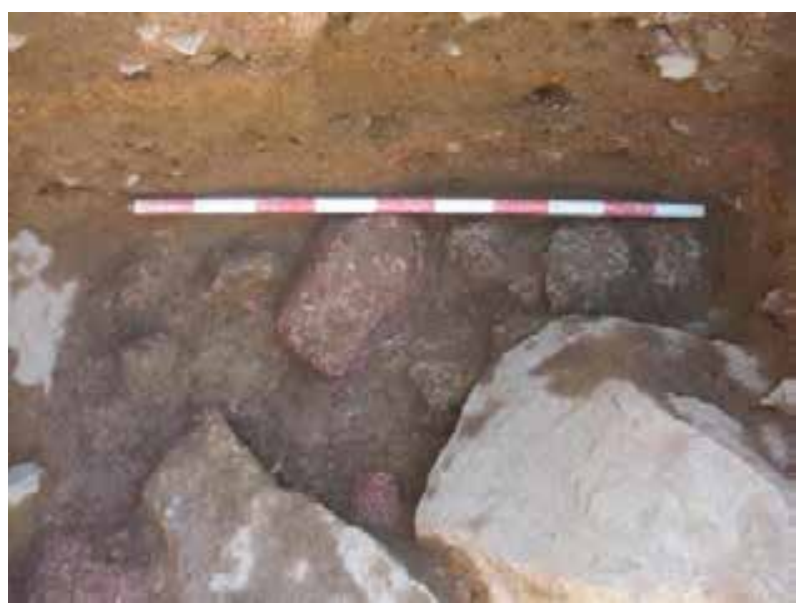

Figura 6

que solo se ha podido documentar en aquellas zonas donde el suelo de granito no se conservaba bien. La excavación del sondeo finaliza con la documentación del nivel de uso UE 7955 que queda sellado por un estrato limoso de abandono (UE 7953).

Concentrado junto al perfil este del sondeo, aparecieron unos bloques compactos de granito rosa (UE 7941) (fig. 6), algunos de los cuales presentan caras planas y están cubiertos por carbonatos. Sin haber podido excavar más en extensión es muy difícil interpretar la presencia de los mismos, pero observando el trabajo de estos bloques de granito podemos apuntar que quizá formaron parte del alzado que funcionó con el nivel de uso antes descrito (UE 7955) (fig. 7). Esta estructura quedó colmatada (UE 7942) por un estrato muy arcilloso con pellas de granito que a medida que se profundizó en la excavación se iban haciendo más grandes, mezclándose con piedras de pequeño tamaño. Cubriendo el nivel de colmatación se constató el desprendimiento natural de piedras procedentes de la ladera, concretamente dos grandes piedras calizas localizadas en el centro del sondeo. Este primer nivel de ocupación quedó colmatado por varios niveles de vertidos que buzan en sentido oeste (UEs 7836, 7936, 7938, 7939 y 7940) (fig. 8). Dentro del conjunto se documentó además una madriguera (UEs 7935-7937) que fue practicada desde el silo 6487, pero que afectó a los estratos documentados en el sondeo 'G'. El último nivel de vertido se corresponde con la UE 7836, un estrato rojizo anaranjado con abundantes piedras y que buza en sentido oeste-este.

Para poder salvar el fuerte buzamiento de los estratos anteriores y preparar el nivel de uso que da paso a la ocupación $\mathrm{B}$, se documentó una acumulación de piedras y tierra (UE 7934) como aporte

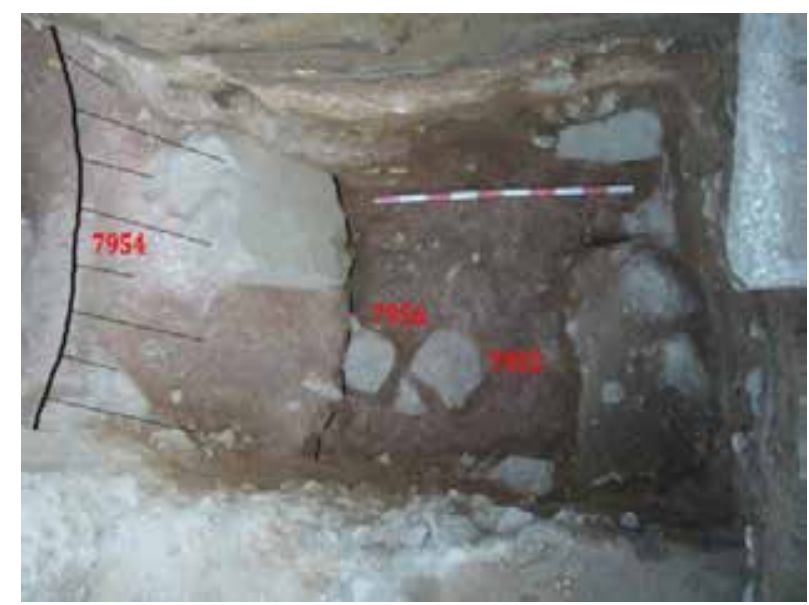

Figura 7

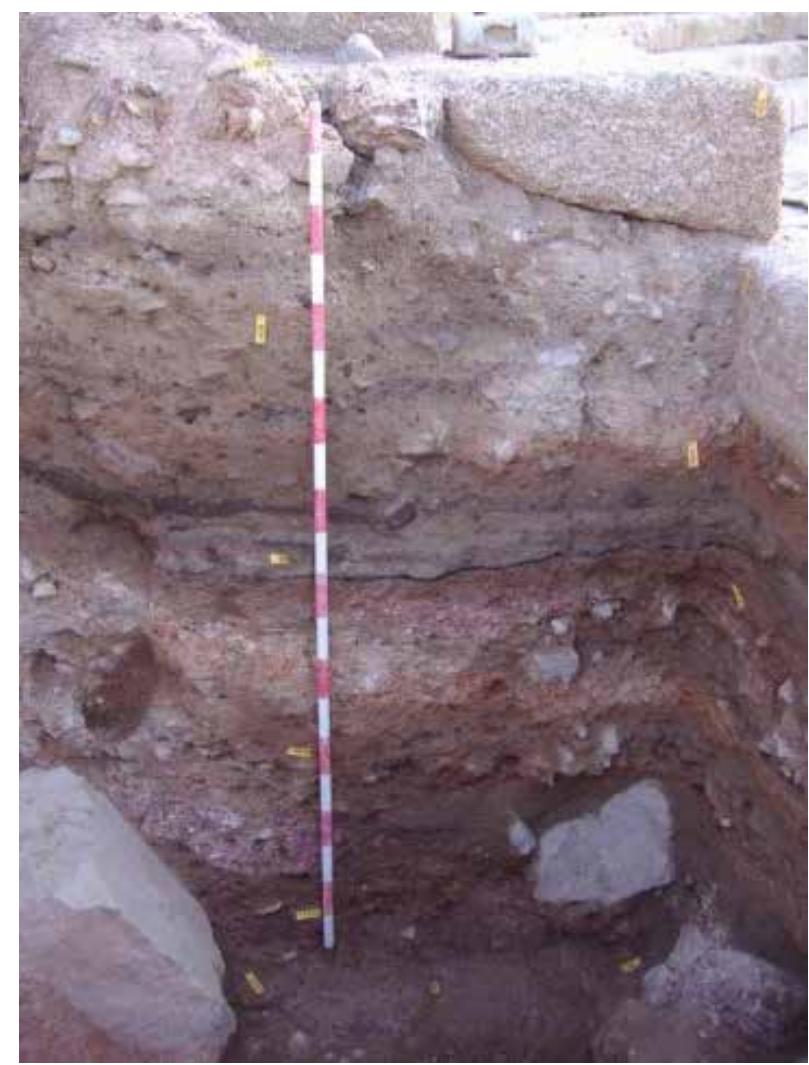

Figura 8

antrópico para recuperar cota y conseguir una superficie horizontal. Una capa de granito disgregado (UE 7933) compacta y regulariza esta concentración de piedras, cumpliendo la función de estrato de nivelación para recibir un nuevo nivel de uso (UE 7926). Se trata de un estrato de color rojizo, de textura arenosa-arcillosa que se sitúa sobre los dos estratos de nivelación (UEs 7933 y 7934). Solo 
fue excavado en la mitad norte, dejando el resto de la unidad en reserva para futuros trabajos de excavación. Este nivel del uso (UE 7926) apareció colmatado por un nivel de limos grisáceos (UE 7925) y una acumulación de piedras (UE 7927) que lo cubren parcialmente. Se localizan en la zona sureste del sondeo y continúan por debajo del perfil. Dadas las reducidas dimensiones del sondeo no podemos interpretar su funcionalidad, pues podría tratarse del derrumbe de piedras procedentes de algún tipo de construcción asociada al nivel de uso UE 7926, pero es algo complejo de identificar.

Tras el abandono de este nivel de uso (UE 7926), se inicia la fase $\mathrm{C}$, donde se registran tres momentos de ocupación (fig. 9) relacionados con la construcción y reforma de una estructura de combustión a la que se asocian varios niveles de uso y abandono. Huelga decir que al no haberse documentado restos de escorias o desechos de alguna actividad concreta, entendemos que esta estructura de combustión es de carácter doméstico; sin embargo, dadas las dimensiones del sondeo poco podemos concretar

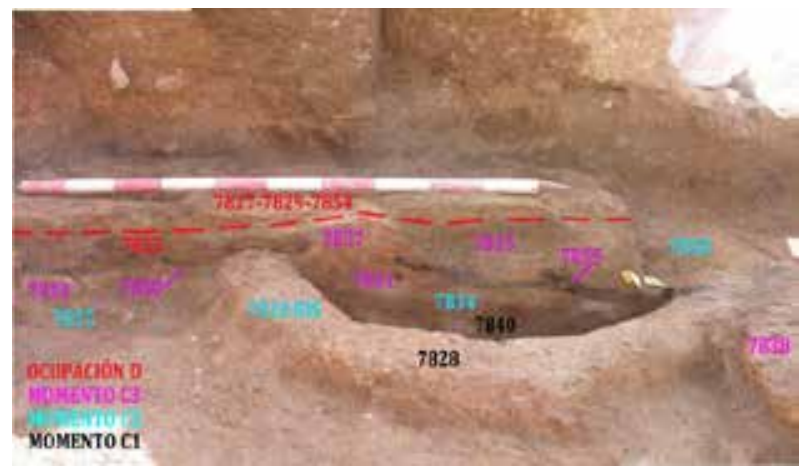

Figura 9

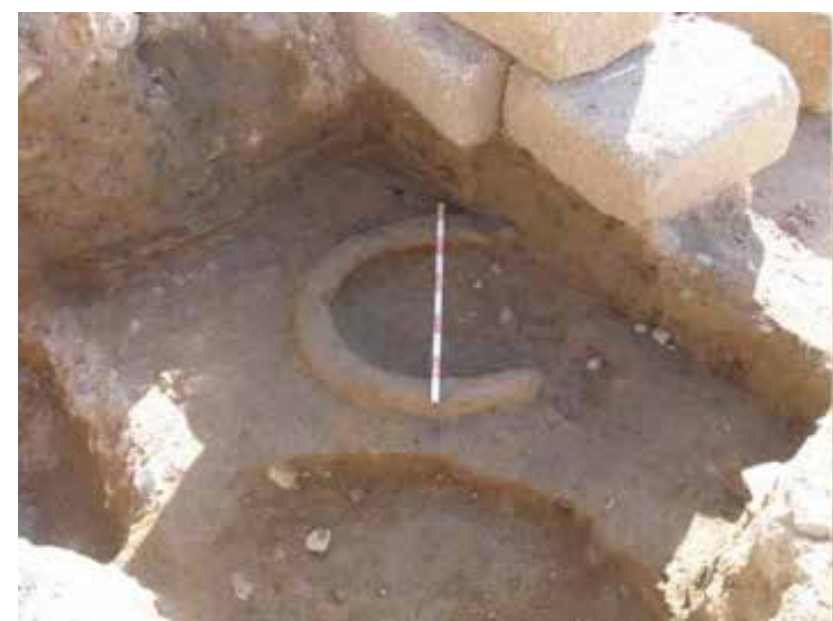

Figura 10 acerca de su emplazamiento en relación con una posible vivienda.

La primera estructura de combustión documentada (C1) se corresponde con una moldura circular abierta en el lado sur (fig. 10). Funciona con un suelo de cal (UE 7923), construido sobre dos estratos que nivelan y regularizan (UEs $7924-7873$ ). Sobre este suelo aparecieron concentradas en el contorno de la estructura restos de cenizas (UE 7879) que están asociadas al uso de la misma. En cuanto al extremo norte, la lechada de cal no se conservaba bien, dejando ver el nivel de uso UE 7926.

La primera estructura de combustión (C1 - UE 7828) es mixta, formada por una parte rebajada en el terreno y otra construida. Su base está excavada en los estratos de nivelación (UEs 7924 - 7926) y presenta restos de haber estado expuesta al fuego. La parte externa está constituida por una moldura de arcilla muy compacta con forma circular abierta en su lado sureste. Posee un diámetro máximo de $1 \mathrm{~m}$ y apoya sobre los estratos de nivelación. Está colmatada al interior por dos estratos de arenas y arcillas mezclados con arcillas grises y cuarcitas de pequeño tamaño (UEs 7840 - 7860) que se adosan a la moldura y que fueron regularizadas para recibir la superficie de uso posterior.

La primera estructura de combustión (UE 7828) abierta en el lado sur, sufre un primer momento de reforma (C2) (fig. 11) consistente en el cierre de la misma con granito disgregado mezclado con arcillas muy compactas (UE 7858), lo que da como resultado una estructura circular completamente cerrada de $1 \mathrm{~m}$ de diámetro al exterior. En su interior, se diferencian tanto un conjunto de adobes que sirven de parapeto para el fuego (UE 7846),

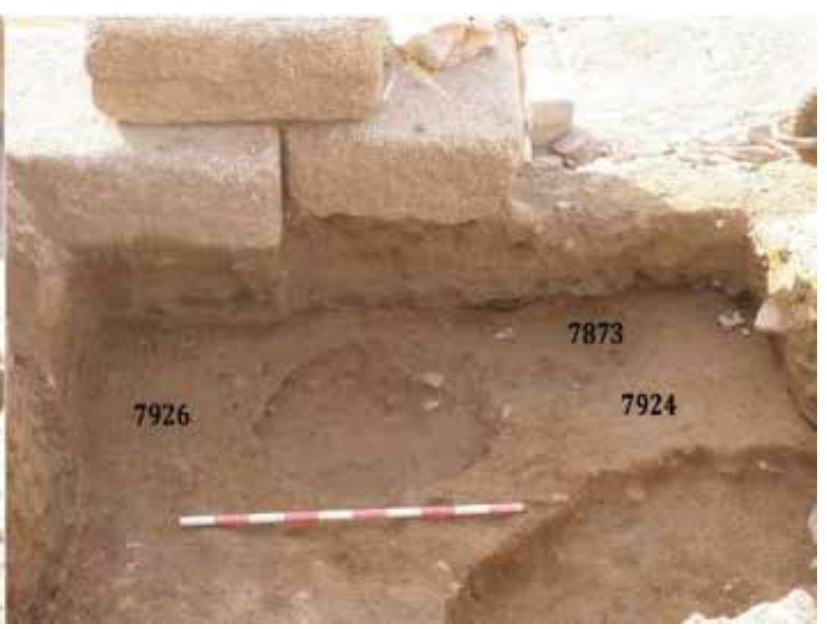


como la superficie rubefactada (UE 7834) fruto de la combustión (fig. 12). Ambas unidades apoyan sobre los niveles de colmatación (UEs 7840 - 7860) de la primera estructura (C1) que han sido regularizados para acometer la reforma. Asociada a esta segunda estructura en el lado sur se documentó una cubeta (UE 7876) colmatada por carbones que seccionan el nivel de uso. Dicho nivel (UE 7835) sella los estratos anteriores, aunque solo se documenta con claridad en el exterior y al norte de la estructura de combustión. Presenta una composición muy compacta a base de piedras mezcladas con arenas y arcillas blanquecinas que se adosan a la estructura. Mientras, en el flanco sur, la estratigrafía no es tan uniforme y muestra varios estratos utilizados como superficies de regularización y de uso (UE 7874). También queda a la vista la UE 7873, parcialmente cubierta por la UE 7874, empleada, junto con la UE 7835 , como niveles de uso al norte de la estructura.

La estructura de combustión cuenta con una tercera reforma (C3) (UEs 7837 - 7838), la primera documentada durante las labores de excavación y la que motivó la ampliación del sondeo (fig. 13). También de forma circular, está construida a base de granito disgregado lo que le da una consistencia muy compacta. Así, la UE 7837 cerraba la estructura por su lado norte y la UE 7838 por el sur, viéndose afectada en este punto por la presencia de un silo islámico (UE 6494). Mientras, el nivel de uso que se adosa a sus paredes (UE 7831) está compuesto por arcillas rosas muy limpias. Por último, se detectaron en el interior de la misma dos estratos de cenizas (UEs 7825 - 7855) fruto del posible uso de ésta como un hogar.

El nivel de uso está formado al exterior por un suelo de arcillas sobre el que se ha colocado una fina capa de cal (UE 7833) que presenta mejor estado de conservación en las zonas este y norte del sondeo. Esta capa de cal está cortada por cuatro agujeros de poste (UEs 7832-7856-7857-7878) de unos $7 \mathrm{~cm}$ de diámetro y $7 \mathrm{~cm}$ de profundidad que se distribuyen hacia el perfil norte del sondeo, por lo que no podemos confirmar si están relacionados con la estructura de combustión o con otras construcciones que pudieran existir fuera de los límites de la excavación. Al exterior y en el extremo sur esta capa de cal no es homogénea, lo que deja entrever la existencia de diferentes estratos dentro de los cuales se conserva muy bien uno de arcillas (UE 7872) junto a la estructura de combustión. Se trata del nivel que sella la cubeta anterior y prepara la superficie de

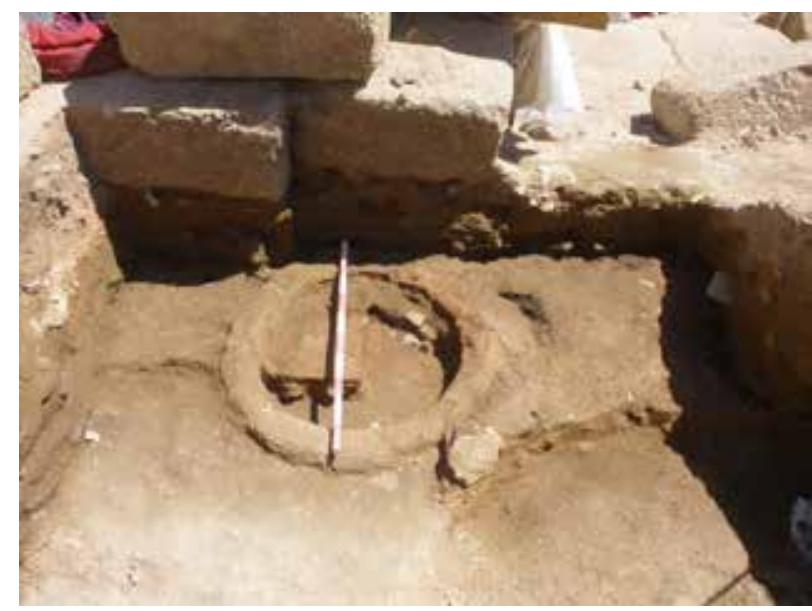

Figura 11

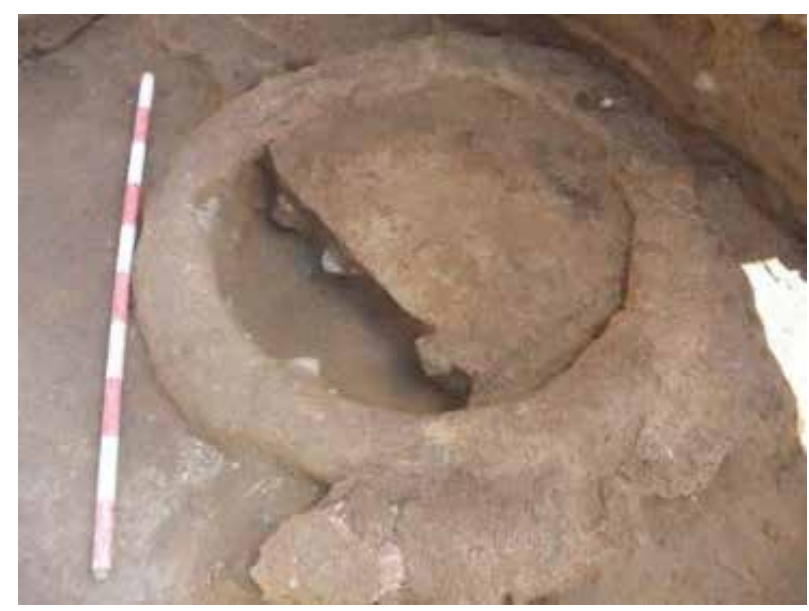

Figura 12

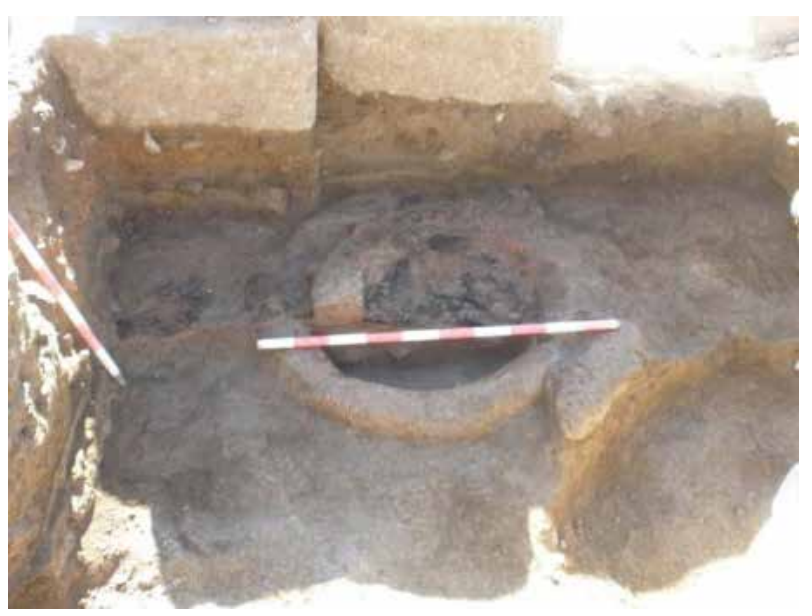

Figura 13 
uso (UE 7833) para este momento. Este suelo de cal quedó tapado con un nivel de cenizas negras poco compactas y de escaso espesor (UE 7830) que junto con la UE 7855 se adosan y cubren parcialmente la estructura de combustión.

Un último nivel de ocupación (ocupación D), se encarga de amortizar la estructura de combustión anterior y los niveles asociados a ella. Se trata de un estrato de unos 3-4 cm de espesor (UE 7927) de composición arenosa y arcillosa, muy compacto, de color verdoso, en el que se han utilizados piedras muy pequeñas mezcladas con arcillas y con restos cerámicos para conseguir una alta compactación. Este estrato amortiza los niveles anteriores sellando y regularizando la superficie en la zona sur.

Varias estructuras tienen relación con el uso de este suelo. Junto al perfil norte se localizó un agujero de poste (UE 7824) y en la zona central del sondeo una serie de piedras dispuestas en círculo (UE 7852-7929) (fig. 14) en cuyo interior no se ha

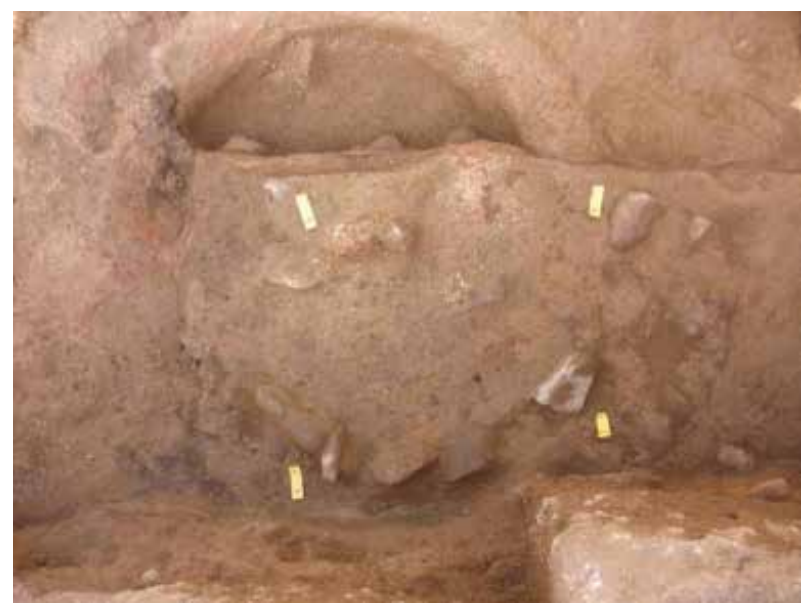

Figura 14

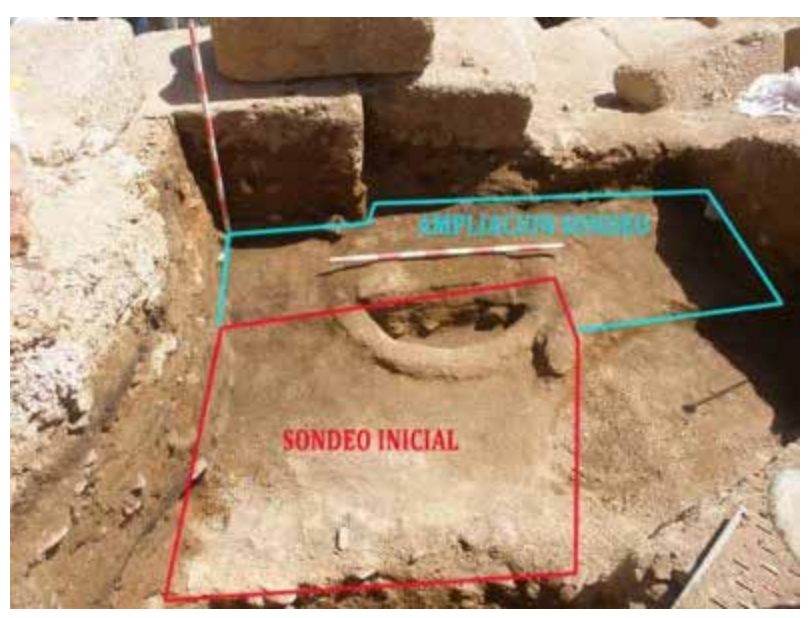

Figura 15

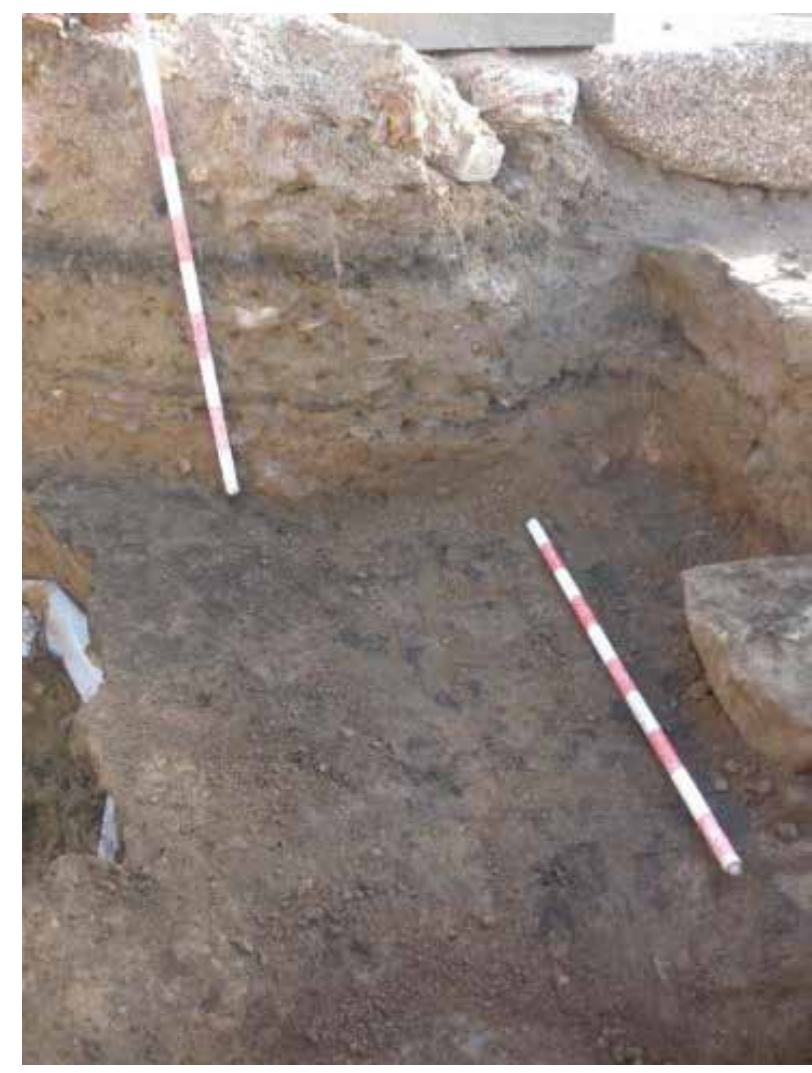

Figura 16

detectado ningún tipo de actividad; sin embargo, su disposición en planta coincide con la ubicación de la estructura de combustión, lo que nos indica la reutilización del espacio en varios momentos distintos. La aparición de esta estructura de piedras motivó la ampliación del sondeo (fig. 15), espacio en el que se documentó una fosa delimitada con piedras y colmatada por cenizas (UEs 7843-7844) que corta el nivel de uso.

Por encima del suelo se detectó un estrato de abandono de cenizas ocres (UE 7823) sellado por un nivel de cenizas negras más homogéneas y restos de un posible incendio (UE 7822) (fig. 16) que cegaban el agujero de poste (UE 7924). Este estrato estaba cubierto por niveles de colmatación de arenas y cenizas (UEs 7820 - 7821) (fig. 17) afectados por el corte practicado en el sustrato para encajar las gradas.

\subsubsection{Materiales}

El lote de materiales recuperado en el sondeo 'G' del cerro del Castillo de Medellín destaca por su homogeneidad. Aunque la muestra documentada durante las tareas de excavación era mucho mayor, 
para este trabajo únicamente se han tenido en cuenta aquellas formas que permiten realizar una valoración cronocultural de la ocupación; un total de 119 fragmentos entre bordes, bases y piezas decoradas. Para el estudio tipológico de las cerámicas hemos recurrido a la consulta de lotes de materiales documentados en yacimientos cercanos (Enríquez Navascués, 1990; Barrientos Vera et alii, 1999). Para ello, hemos rastreado la presencia de determinados ítems que se repiten en todos ellos, caso de las cazuelas carenadas o los platos de borde almendrado.

En una valoración global del conjunto de materiales recuperados, podemos destacar, por tratarse de las formas más numerosas, los vasos, recipientes de paredes altas y rectas, y los cuencos, de tendencia esférica y globular. Junto con ellos resalta la presencia de platos de borde almendrado y los de borde reforzado, ambos representativos de este período; mientras, las cazuelas carenadas parecen estar ausentes en esta secuencia, aunque algunos de los bordes apuntados de suave carena podrían ser incorporados dentro de este grupo tipológico, no sin algunas dudas. Lamentablemente, no ha podido recuperarse ninguna pieza completa y muchos de los bordes documentados son de pequeño tamaño, tanto para determinar el diámetro de la pieza como su funcionalidad. A pesar de ello, la muestra recogida nos permite realizar una pequeña valoración cronotipológica de los niveles de ocupación en los que han sido localizados los restos.

En cuanto a los acabados o tratamientos de las cerámicas, se detecta una preferencia por los alisados, dentro de los cuales se pueden distinguir una amplia gama de calidades, desde superficies muy cuidadas, menos porosas, hasta piezas con escaso tratamiento que hacen que los recipientes presenten unas superficies muy irregulares. Este último grupo destaca también por presentar pastas poco depuradas, con desgrasantes minerales muy gruesos, fundamentalmente de cuarzo, que afectan también al acabado y calidad de la pieza. Solo seis fragmentos de toda la muestra recogida presentan un tratamiento bruñido al exterior (7820-28; 7840-50; 7817-1; 7924-8; 7942-5/2), lo que les da a los recipientes un aparente acabado metálico. Por su parte, las cocciones son irregulares, predominando los ambientes reductores. Así, la tonalidad de las pastas varía entre tonos ocres, marrones, grises y negros, principalmente al exterior del recipiente.

Teniendo en cuenta el grado de arrasamiento que han sufrido los estratos localizados bajo el graderío

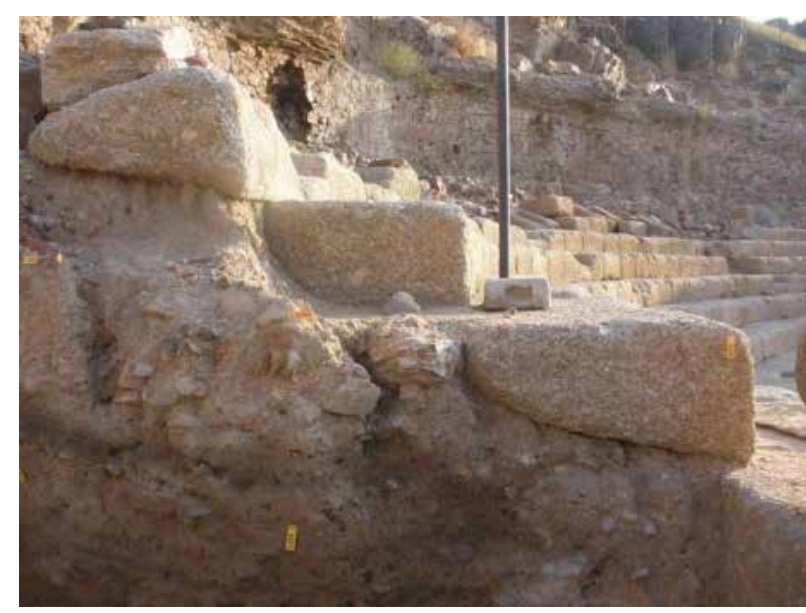

Figura 17

del teatro romano y a pesar de la homogeneidad del lote de cerámicas recuperadas en el sondeo 'G', hemos considerado exponer el material estudiado en dos niveles diferenciados. El primer nivel incluye los materiales hallados en las UEs 7817, 7818, 7819, 7820,7821 y 7822 (fig. 18, 19, 20, 21 y 22), afectadas por la nivelación del terreno para la colocación de los sillares que conforman el graderío del teatro, así como por la ejecución de varios silos de cronología medieval. A pesar del grado de afección de estas unidades, el material cerámico más abundante corresponde a la etapa calcolítica; sin embargo, dentro de la unidad 7819, estrato sobre el que apoyan los sillares del teatro, se han recuperado varios fragmentos de terra sigillata. Junto con la cerámica romana también se han documentado fragmentos que pueden fecharse en el Bronce Final, caso de un borde de cazuela carenada documentada en la UE 7819 (9) y otro posible en la UE 7817 (1), con paralelos en la fase I del corte SMRO (Jiménez Ávila y Guerra Millán, 2012).

La presencia de materiales del Bronce Final en la ladera sur del cerro del Castillo de Medellín ya había quedado constatada en la secuencia extraída por Del Amo (1973), donde se alude a la existencia de cerámicas bruñidas del Bronce Final, así como en la Cata Este realizada por Almagro-Gorbea (1977), quien fechó en este período el último nivel de la secuencia. Sin embargo, en el caso que nos atañe, únicamente podemos hablar de la presencia de materiales de manera residual, pero no de niveles de ocupación que puedan fecharse en el Bronce Final. La presencia de estos escasos fragmentos se pone en relación directa con su localización en niveles que han sido alterados por los movimientos de tierra, de 
TRM-7818-1

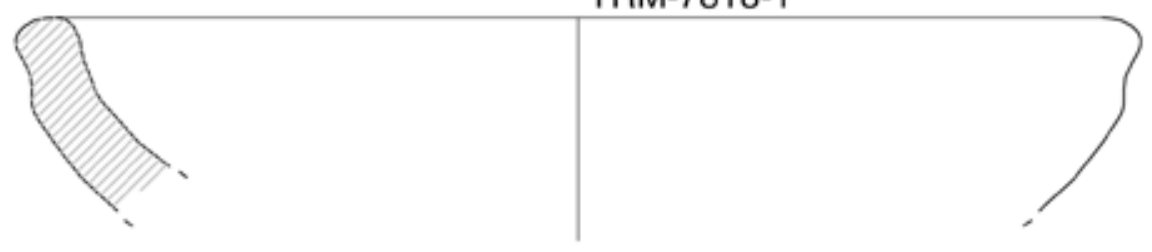

TRM-7818-5"

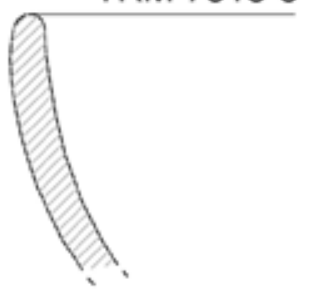

TRM-7818-3

TRM-7818-4
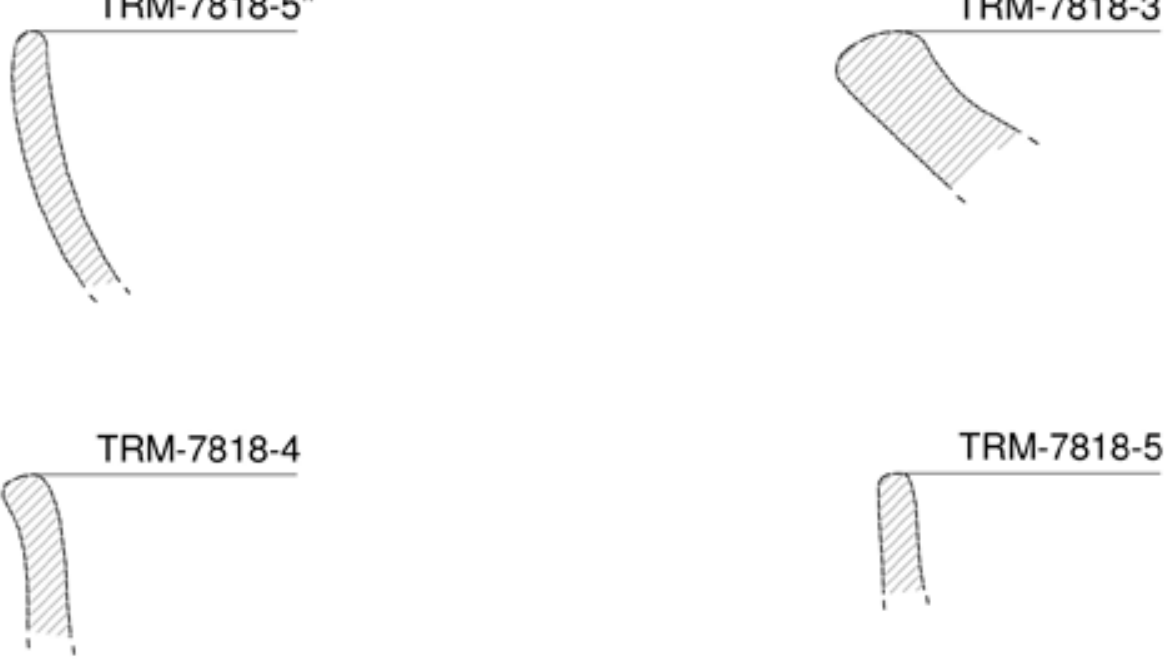

TRM-7818-5

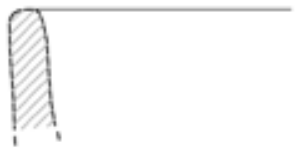

TRM-7818-2

TRM-7818-6
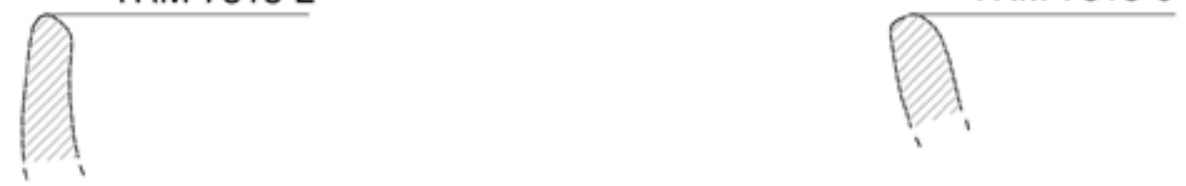

TRM-7818-8

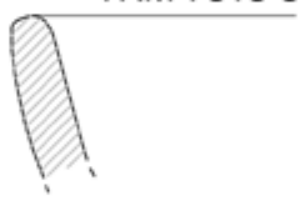

TRM-7817-2

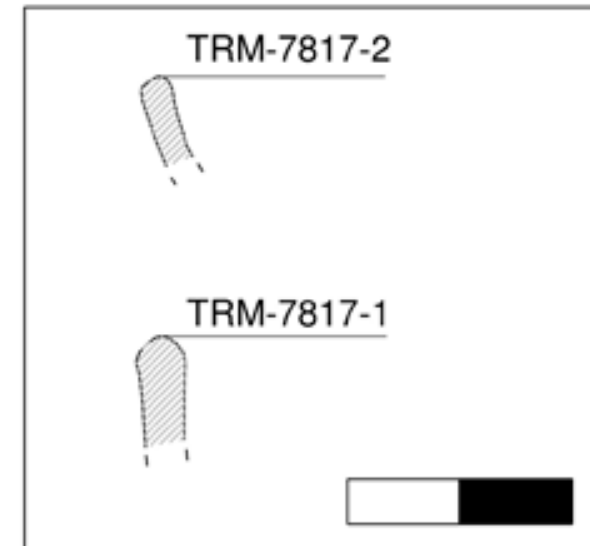

Figura 18 
TRM-7819-2

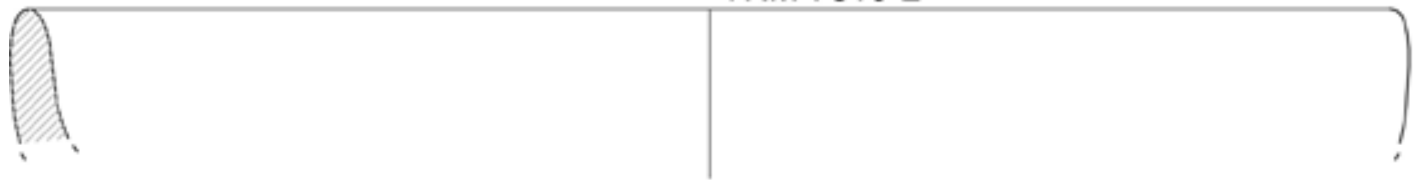

TRM-7819-9

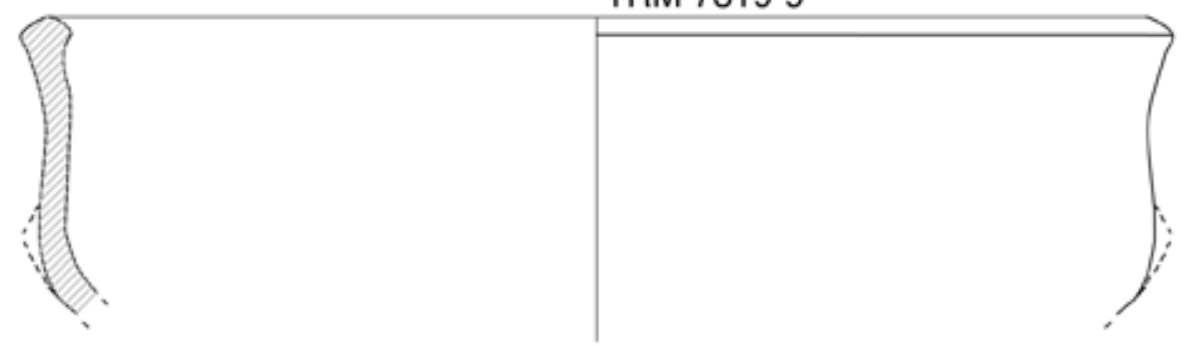

TRM-7819-3

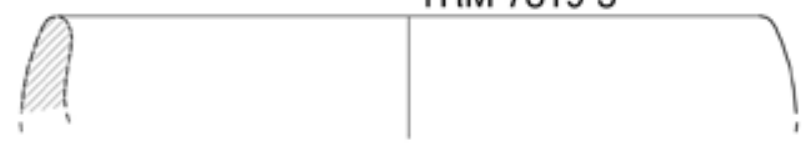

TRM-7819-6

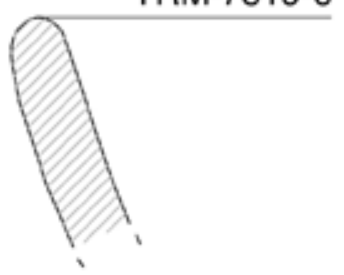

TRM-7819-1

TRM-7819-7
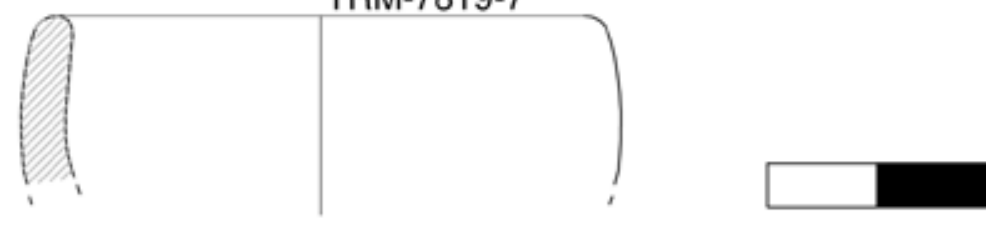

TRM-7819-10
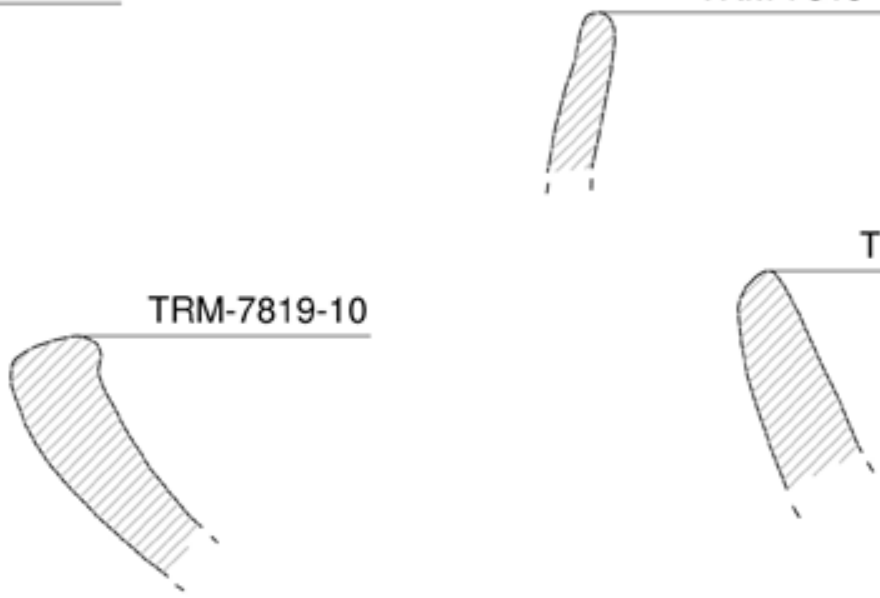

\section{TRM-7819-5}

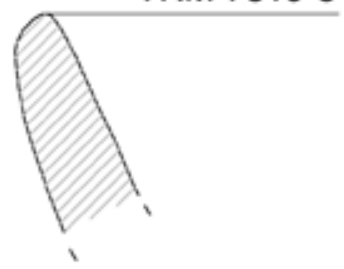

Figura 19 
TRM-7820-4

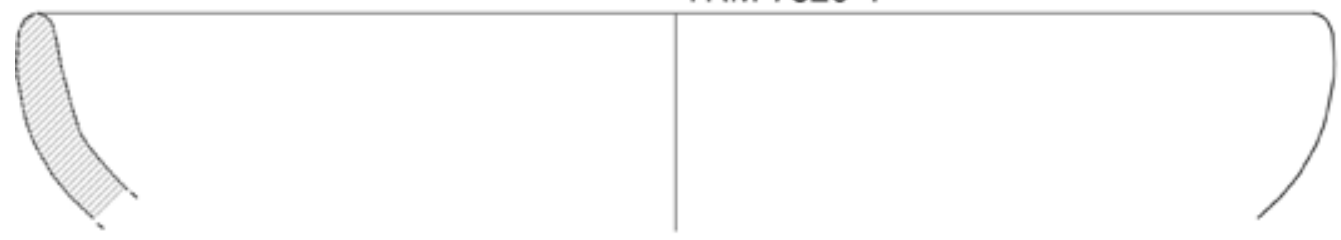

TRM-7820-13

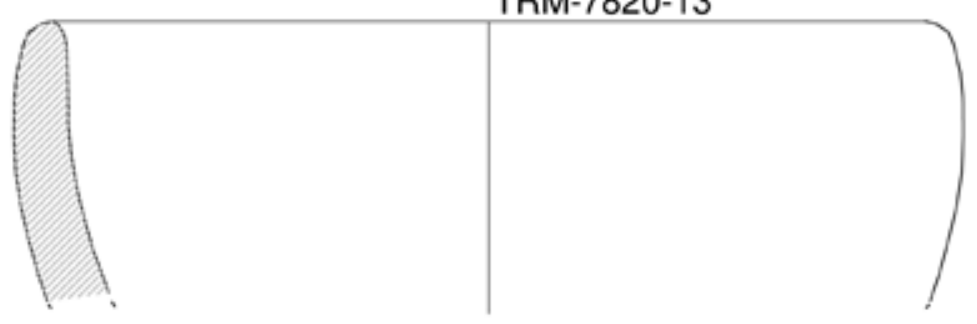

TRM-7820-5

TRM-7820-1

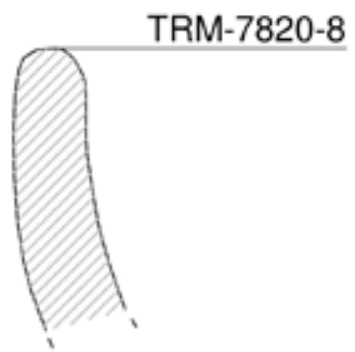

TRM-7820-15

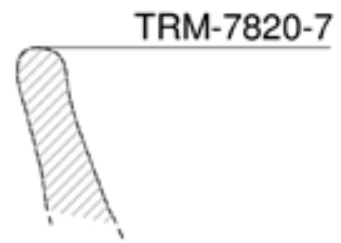

Figura 20

Revista ONoba, 2017, No 05 

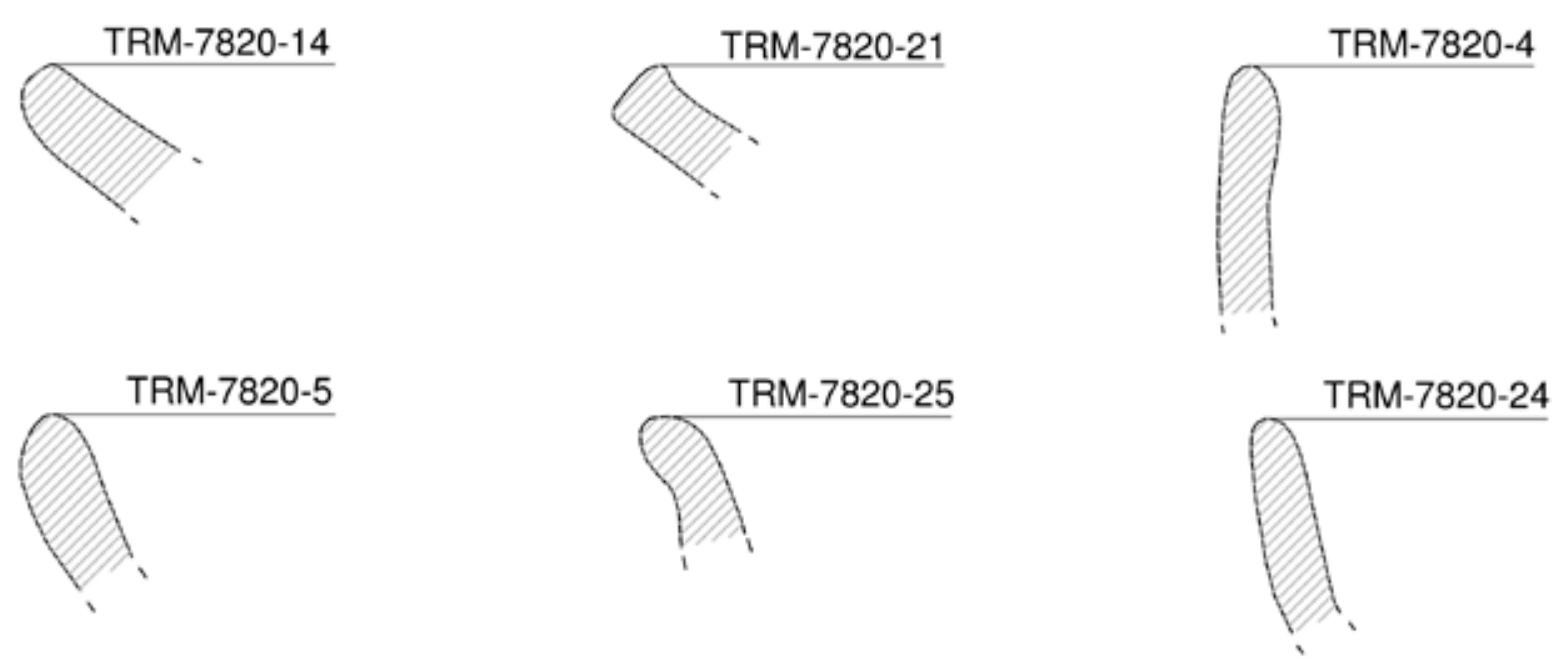

TRM-7820-3
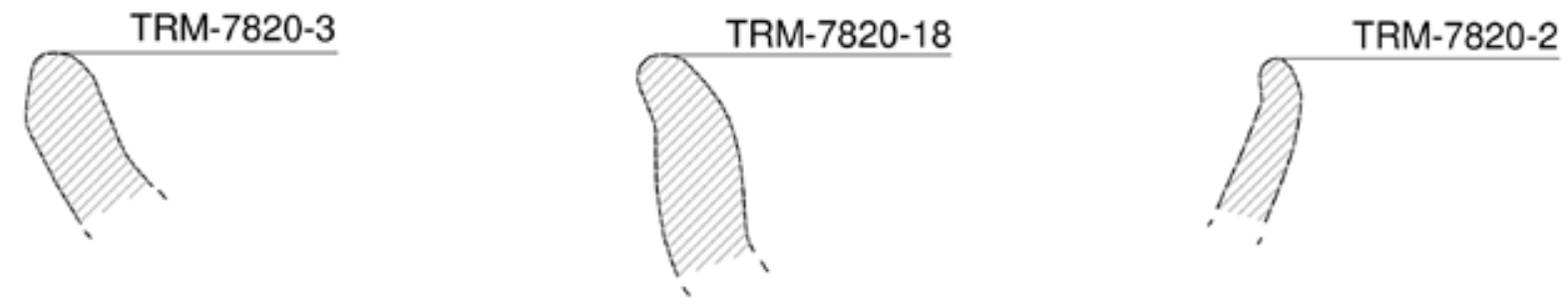

TRM-7820-2

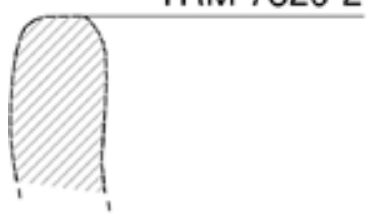

TRM-7820-28

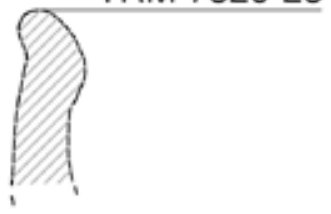

TRM-7820-11

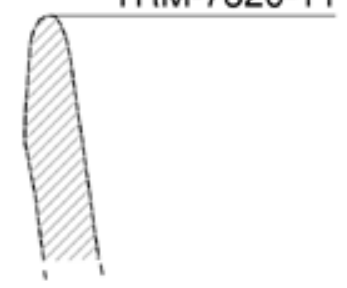

TRM-7820-3
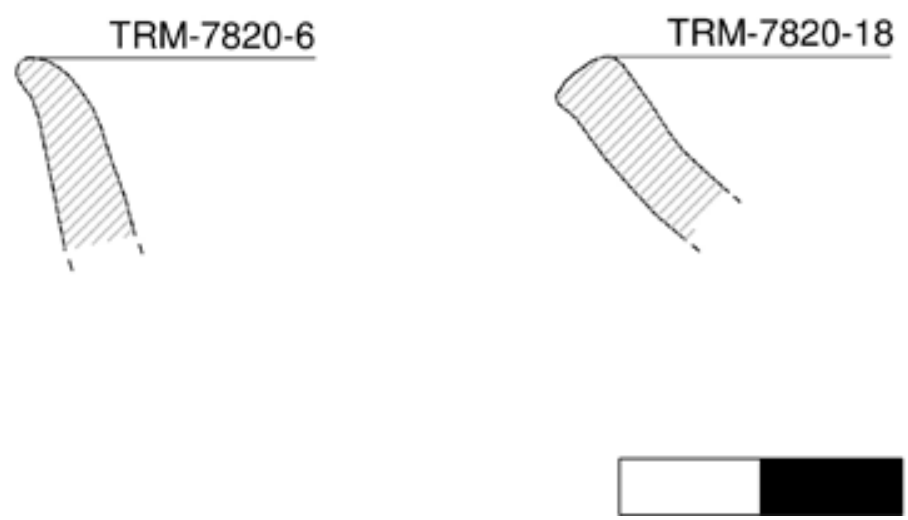

Figura 21 
TRM-7821-3

TRM-7821-4
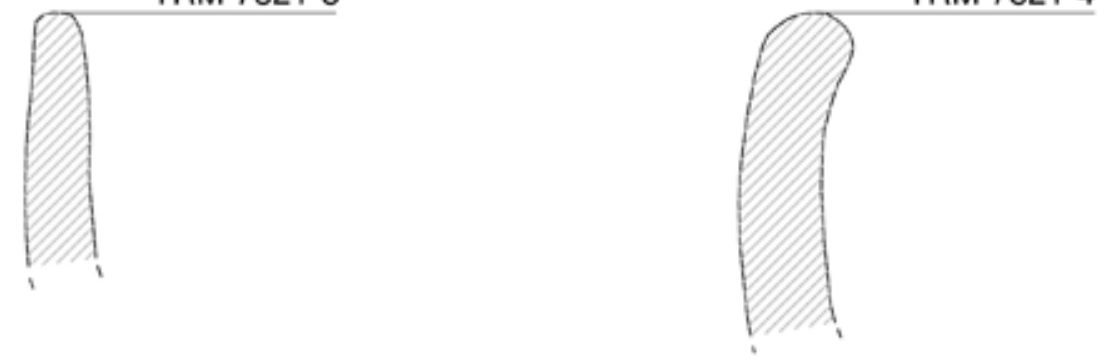

TRM-7821-1
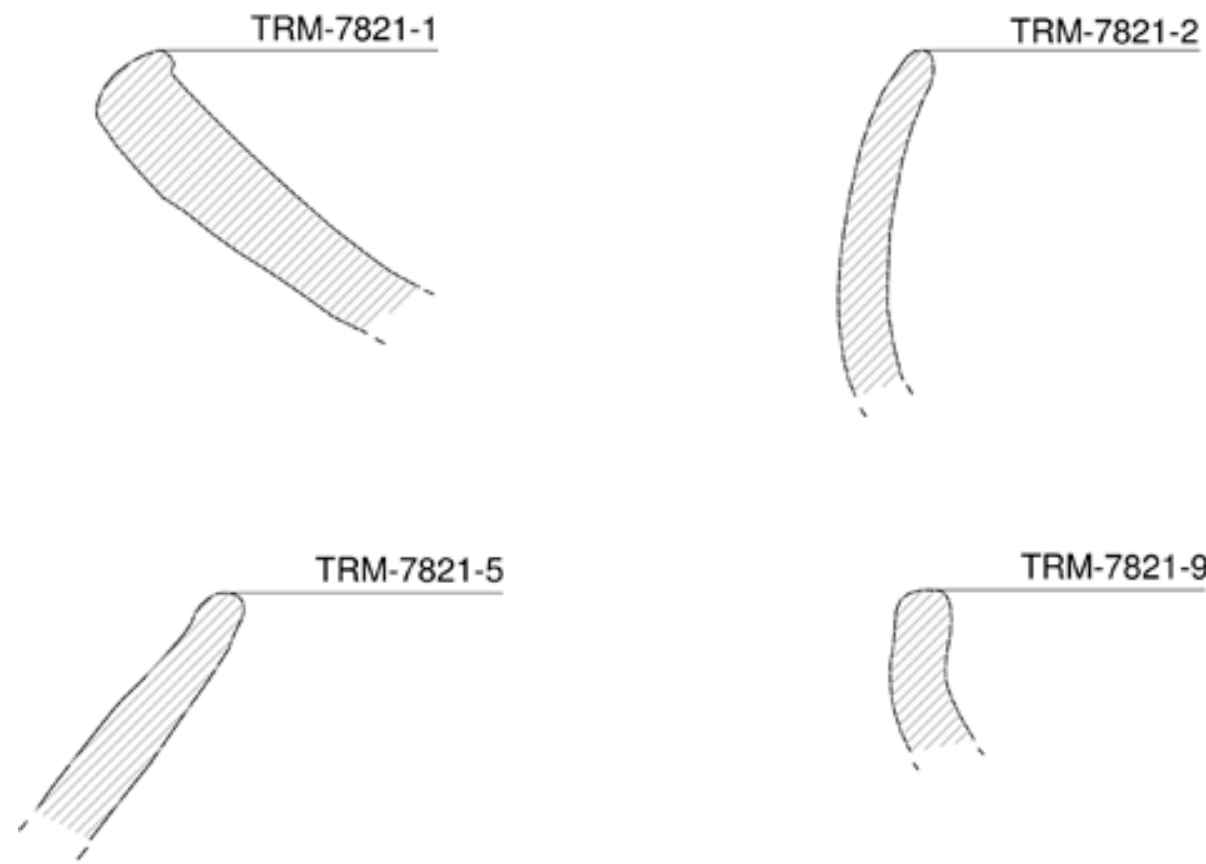

TRM-7821-9

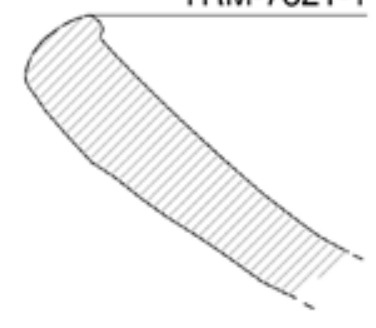

TRM-7821-6

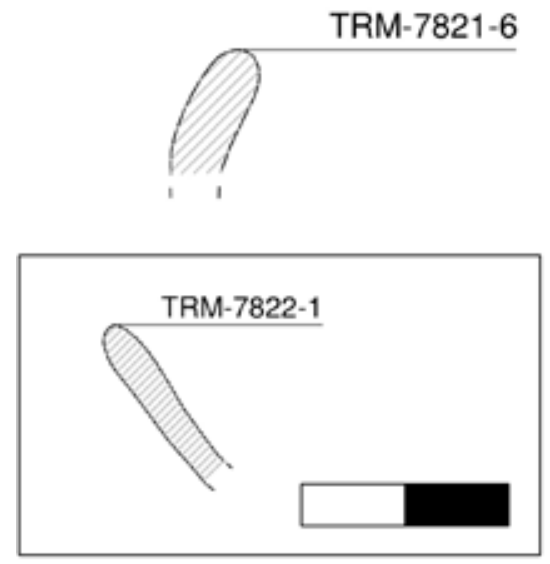

TRM-7821-7

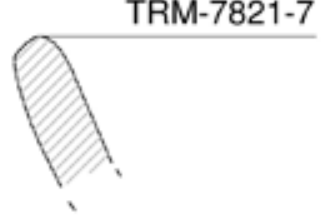

TRM-7821-10

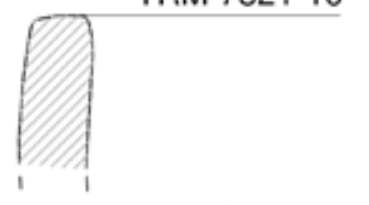

Figura 22

Revista ONoba, 2017, No 05 
ahí que no resulte extraña la aparición de materiales de diversas cronologías.

Entre el material romano y del Bronce Final sobresalen las cerámicas calcolíticas que marcan el inicio de la ocupación. Entre el repertorio destaca la presencia de vasos de paredes rectas y bordes gruesos o globulares de boca cerrada (7820-18; 7820-6) y los cuencos, entre los que podemos citar varios ejemplares de casquete esférico, caso de las formas 7820-4/5. Así mismo, no están ausentes los platos de bordes almendrados y reforzados, representados en las formas 7818-1/3, 7819-10, 7820-21/3/18 y 7821-1.

En el segundo nivel se incluye el resto de la secuencia, a partir de la unidad 7823 (fig. 23), interpretada como un nivel de abandono uniforme bajo el que se disponen los diferentes niveles de uso analizados anteriormente. Al mismo tiempo, este segundo nivel puede ser analizado en dos partes diferenciadas, una primera en la que se engloban las unidades correspondientes a los niveles de uso a los que se asocia la estructura circular (ocupación B-C) y sus correspondientes reformas, $y$ una segunda dedicada a los niveles de relleno bajo la misma y la posible presencia de una cabaña circular (ocupación A). No obstante, aunque separemos los lotes de materiales para su descripción, la homogeneidad de los fragmentos recuperados retrata la existencia de una continuidad dentro de la secuencia.

Este segundo nivel concentra el mayor volumen de materiales, una circunstancia lógica si tenemos en cuenta que es dentro de esta parte de la secuencia donde se concentran los niveles de uso. A ella pertenecen las UEs 7823, 7825, 7827, 7829, 7831, $7836,7840,7844$ y 7924. El elenco de materiales recogido en estas unidades estratigráficas sigue siendo bastante regular, con la presencia destacada de cuencos, caso de las formas 7823-4 y 7827-1 (fig. $24)$, vasos de tendencia globular, como las piezas 7823-7; 7844-2 y 7844-7 (fig. 25) o los platos, representados en formas como la 7840-2.

El porcentaje más elevado de materiales se concentra en las unidades 7836 (fig. 26) y 7924. La primera unidad se corresponde con un nivel de relleno rojizo en el que destaca la presencia de piedras. Entre sus materiales se suceden los cuencos globulares (7836-9) y los vasos de paredes rectas (7836-5), así como dos bordes de plato (7836-7/8/13). Sin embargo, es la pieza 7836-3 la que más llama la atención dentro del repertorio. Se trata de un vaso de paredes rectas, de cocción oxidante, decorado con incisiones paralelas que posteriormente han sido rellenadas. A pesar de la singularidad del fragmento, cabe la posibilidad de que se trate de una intrusión procedente del silo 6487, en cuyo interior se documentaron materiales de diversas cronologías.

En cuanto a la unidad 7924 (fig. 27), este estrato se corresponde con el nivel de preparado sobre el que posteriormente se dispuso la estructura circular. Es una de las unidades cuyo elenco material es más significativo, pues junto con los vasos y cuencos tradicionales se documentaron tres platos, dos de borde reforzado (7924-1/8) y uno de borde almendrado (7924-7), característicos de este período.

Por último, únicamente resta caracterizar los estratos documentados bajo los niveles de uso y la estructura de combustión. Se trata de las unidades 7926, 7927, 7934, 7938, 7939, 7940 y 7942 (fig. 28 y 29). Aunque el repertorio de materiales sigue siendo muy similar al descrito para los estratos anteriores, llama la atención que en los niveles más profundos los acabados de las piezas sean menos cuidados y los recipientes presenten un tamaño mayor. A pesar de ello, cabe destacar entre los restos recuperados un borde con decoración digitada (7942-4) y dos fragmentos bruñidos, uno correspondiente con un vaso globular de boca cerrada (7942-2) y otro con un plato de borde reforzado (7942-5) (Fig. 30). Cabe así mismo distinguir que es en estos niveles donde se localizan algunas formas cerámicas típicas de una fase anterior o Neolítico Final que, sin embargo, parece que perduran durante época calcolítica.

El conjunto de materiales queda completado, por un lado, con los escasos restos de talla lítica, representados por un fragmento de un útil retocado de chert (UE 7840) y dos lascas de cuarcita (UEs 7827 y 7844); y, por otro lado, por tres fragmentos de crecientes (fig. 31), piezas fabricadas con arcilla, de sección cilíndrica y perfil curvado. Dos de ellas se corresponden con pequeños fragmentos que apenas conservan $1 \mathrm{~cm}$ de longitud, los hallados en las unidades 7827 y 7836; mientras que el rescatado en la UE 7840 presenta una perforación en uno de sus extremos y está mejor conservado. La aparición de estos objetos en el cerro del Castillo de Medellín no es novedosa, pues en la secuencia del corte SMRO fueron documentados otros tres ejemplos (Jiménez Ávila y Guerra Millán, 2012, 92). 
TRM-7823-1

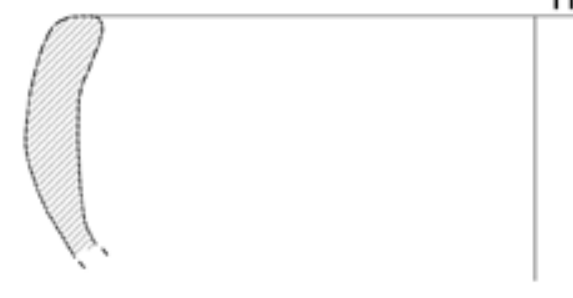

TRM-7823-7

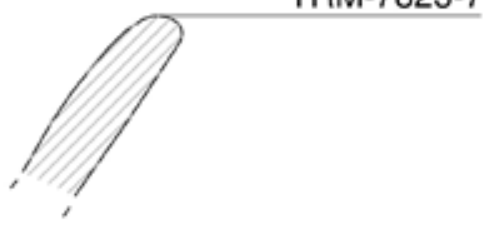

TRM-7823-4

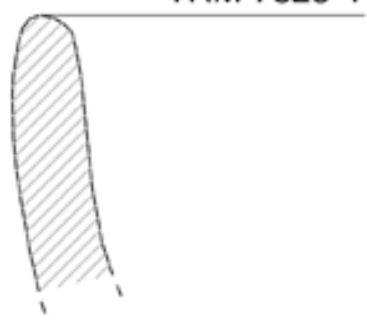

TRM-7823-2

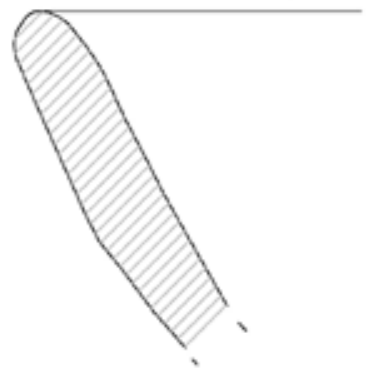

TRM-7823-3
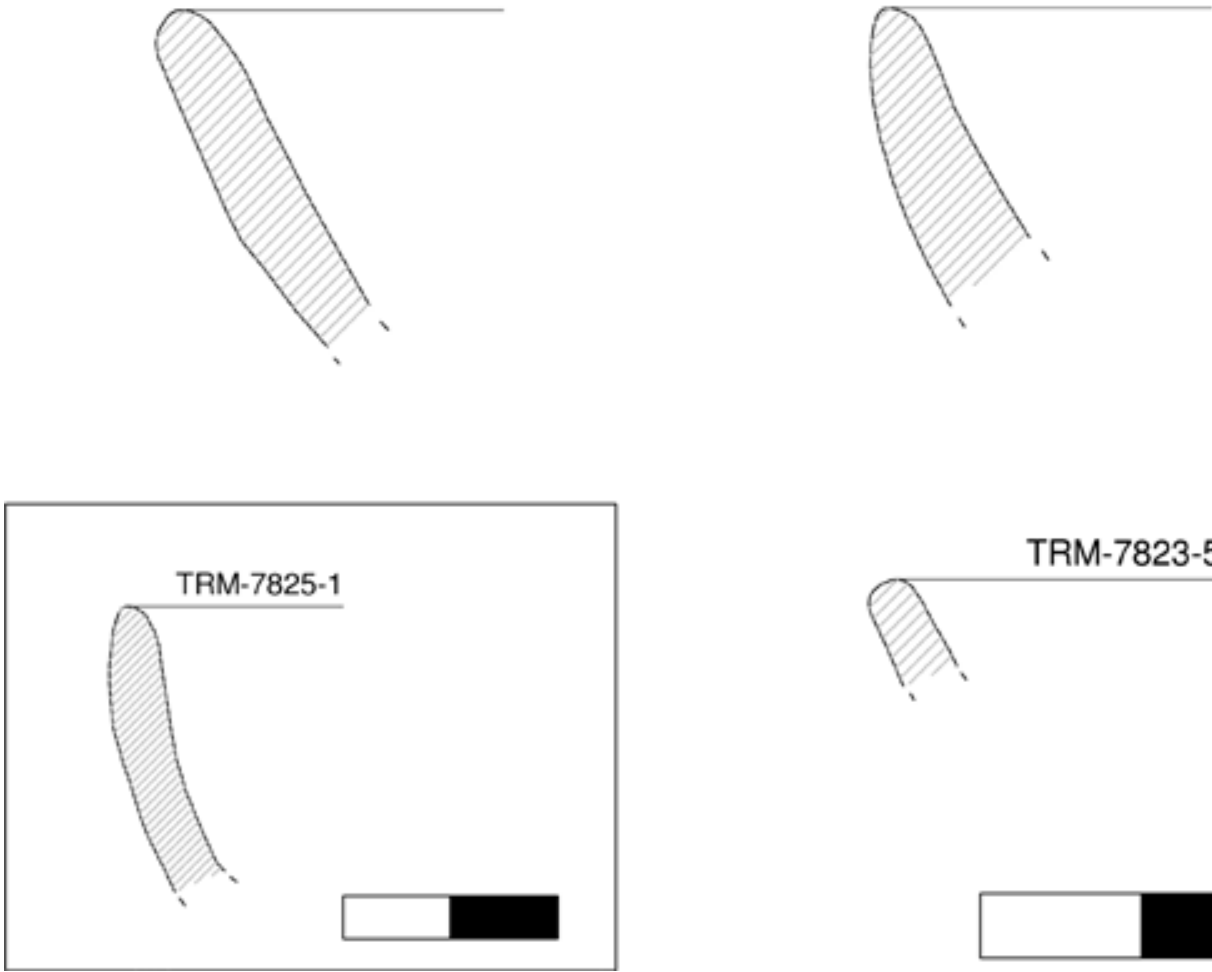

TRM-7823-5

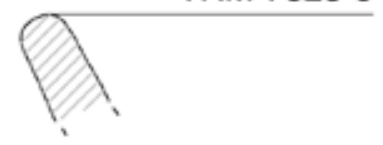

Figura 23

Revista ONoba, 2017, No 05 
TRM-7827-1

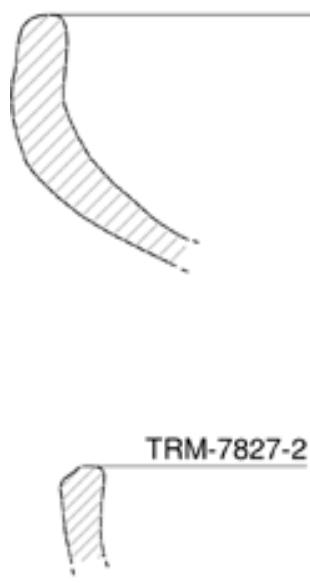

,

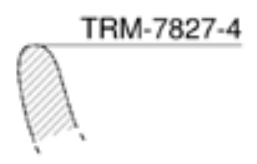

TRM-7827-3

TRM-7829-1
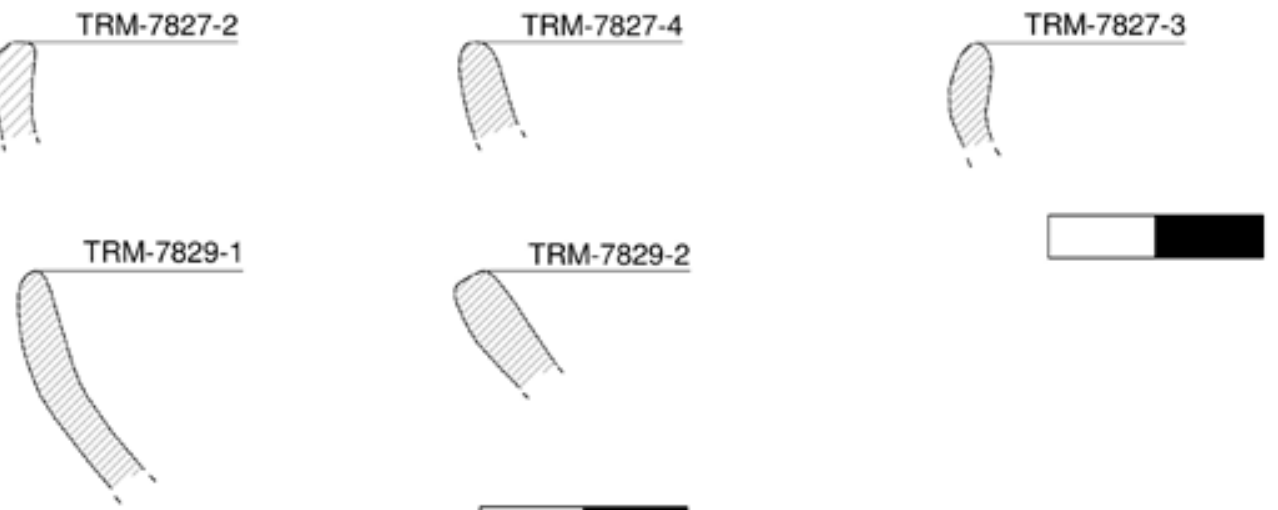

TRM-7829-2

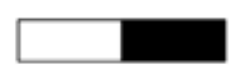

TRM-7831-1

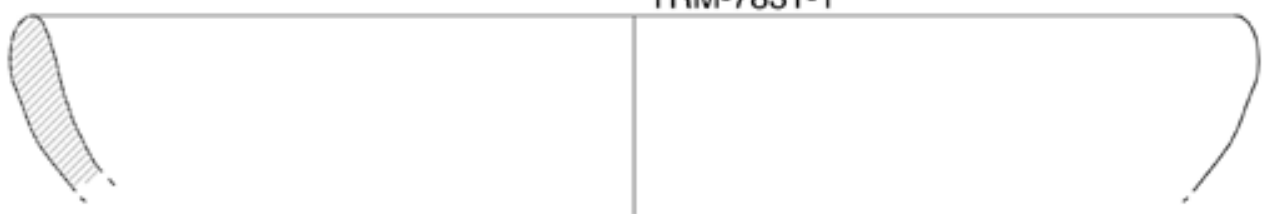

TRM-7840-2

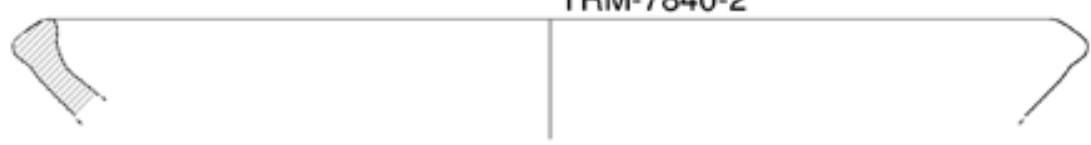

TRM-7840-50
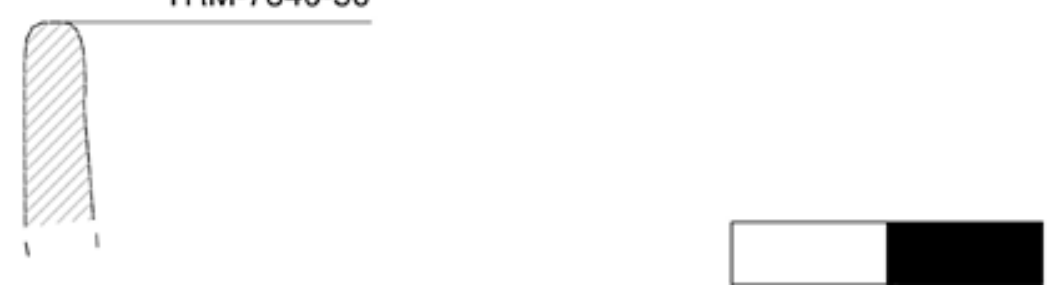

Figura 24 


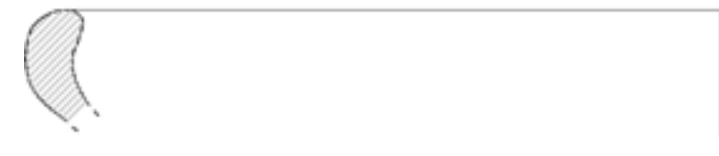

TRM-7844-3

TRM-7844-2
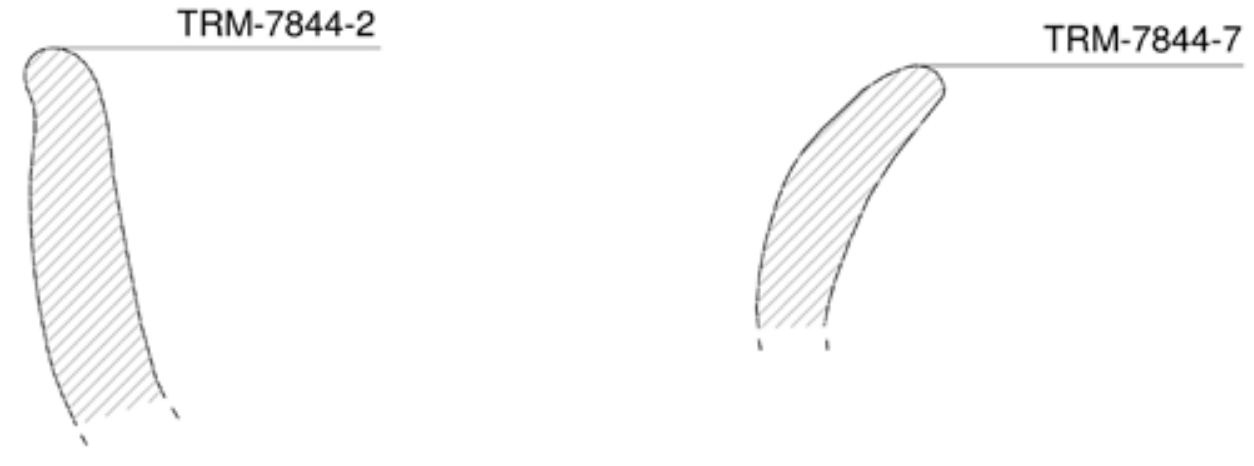

TRM-7844-4
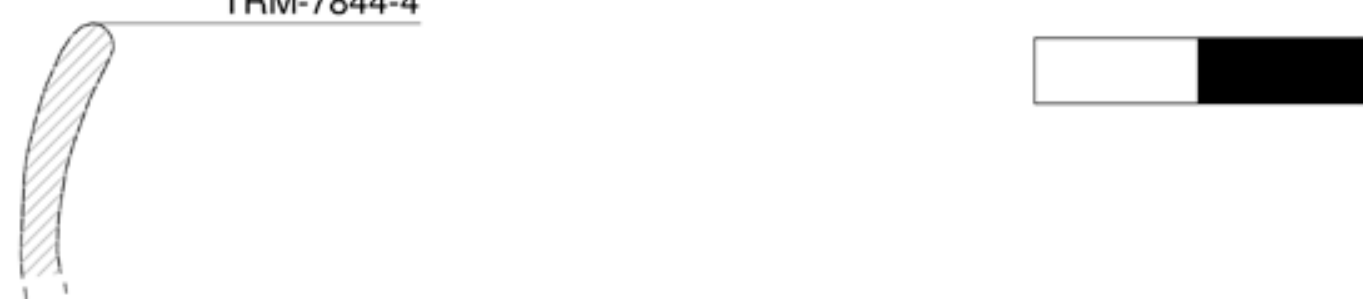

Figura 25

Revista Onoba, 2017, No 05 
TRM-7836-9

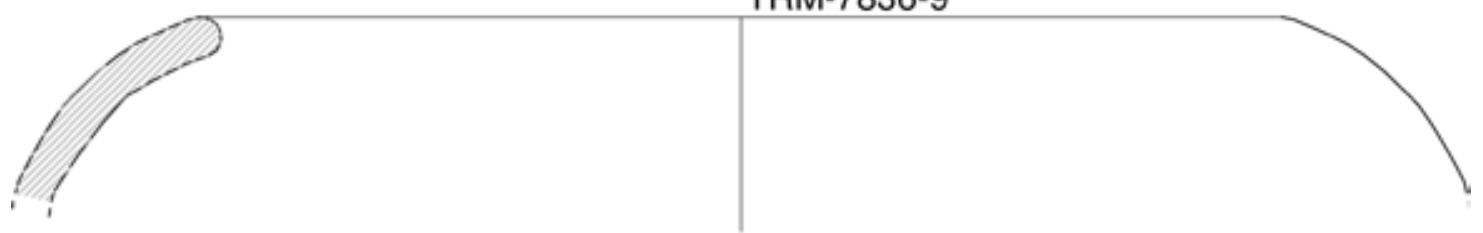

TRM-7836-11

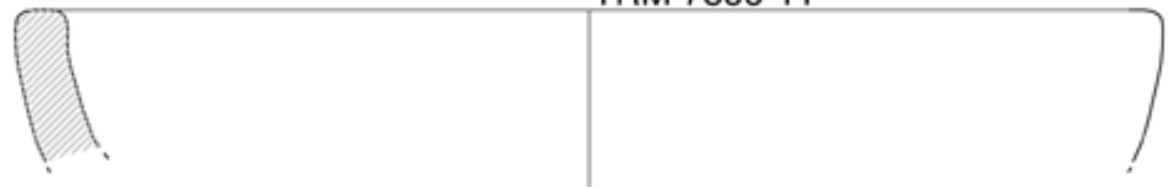

TRM-7836-7/8

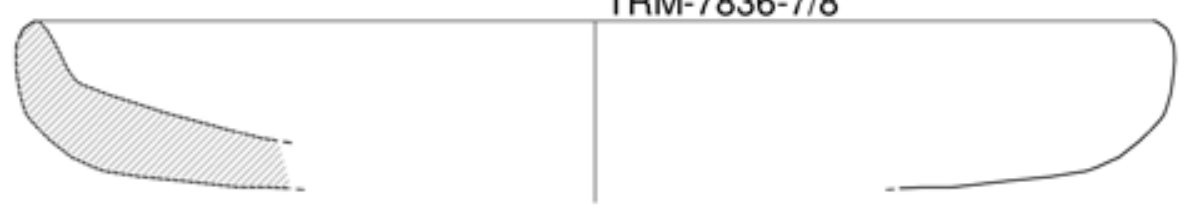

TRM-7836-16

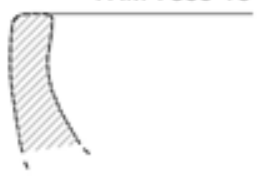

TRM-7836-17

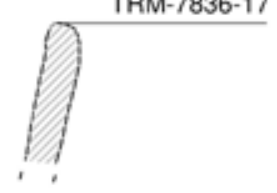

TRM-7836-5
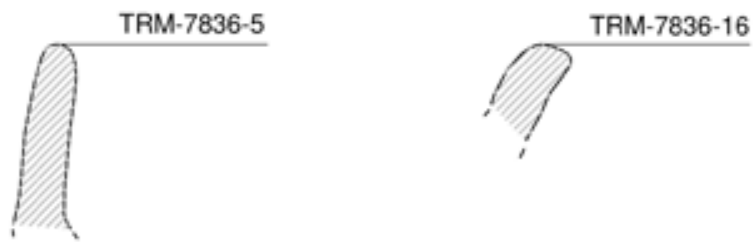

TRM-7836-6
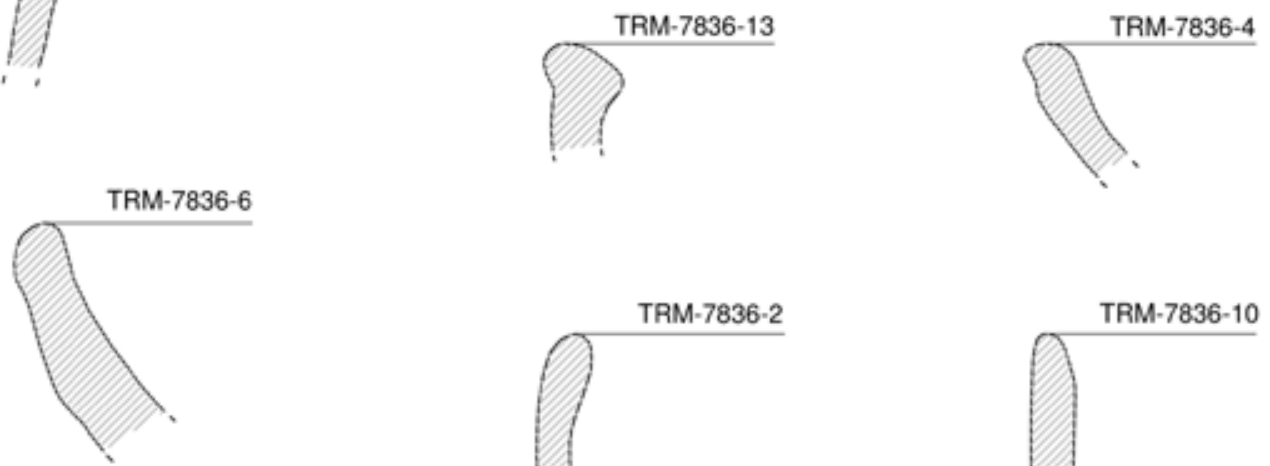

TRM-7836-2

TRM-7836-10

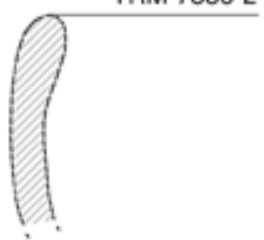

TRM-7836-3
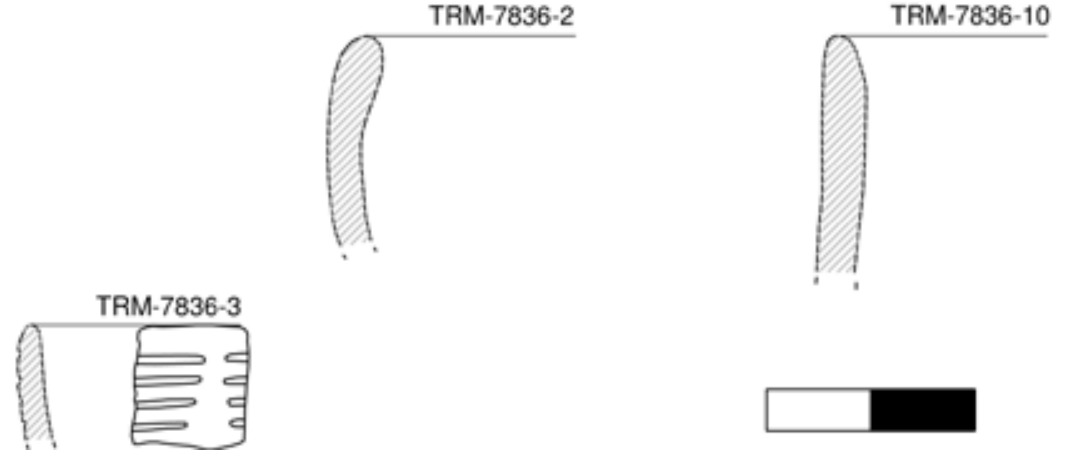

Figura 26 
TRM-7924-1

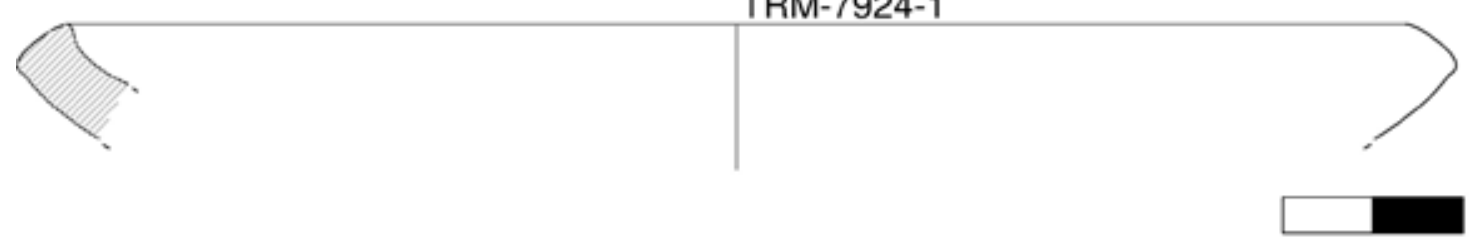

TRM-7924-8
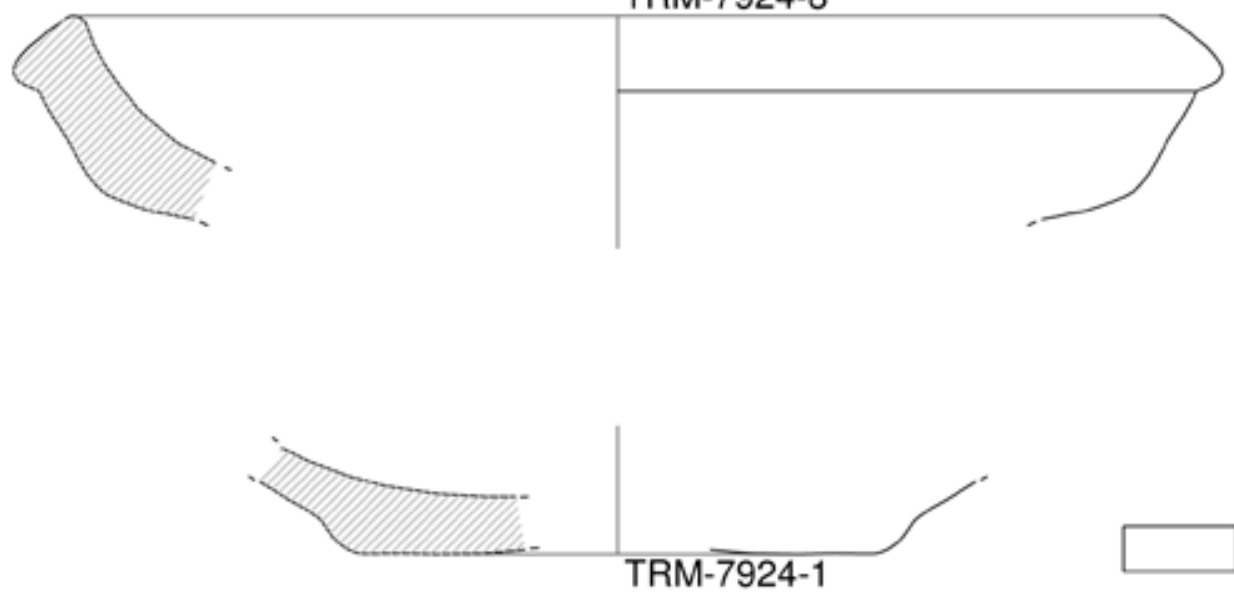

TRM-7924-5

TRM-7924-3

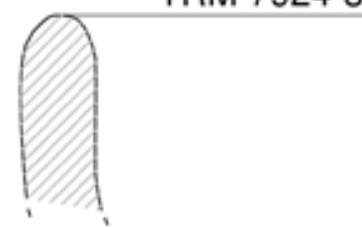

TRM-7924-4

TRM-7924-7

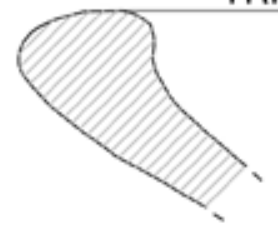

TRM-7924-2

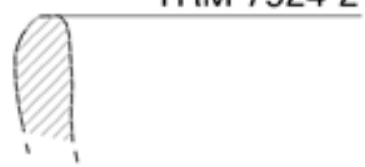

Figura 27 
TRM-7938-5
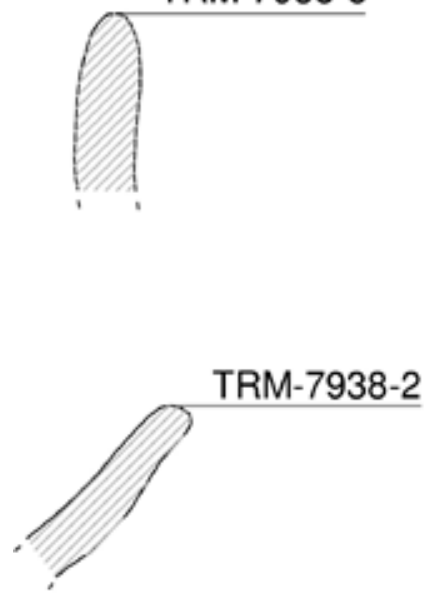

TRM-7939-1

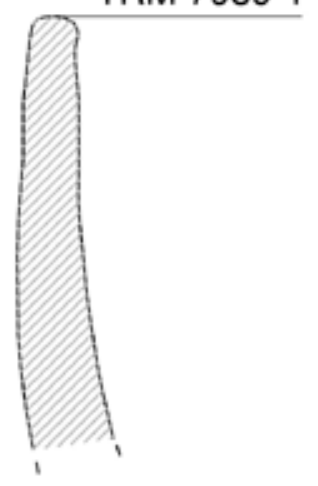

TRM-7939-4

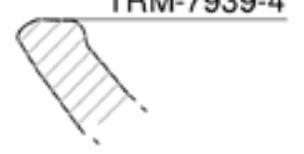

TRM-7938-1

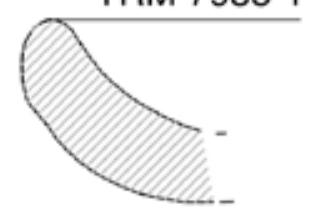

TRM-7938-3

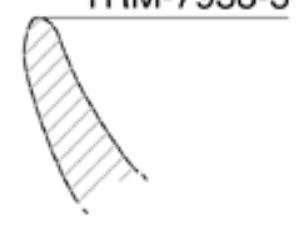

TRM-7939-2

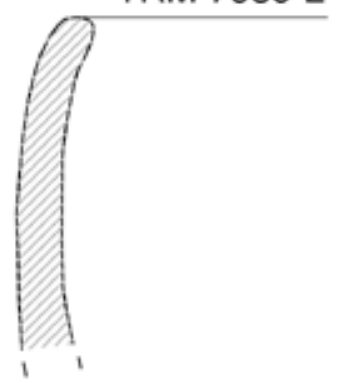

TRM-7939-5

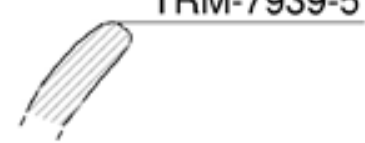

TRM-7938-6

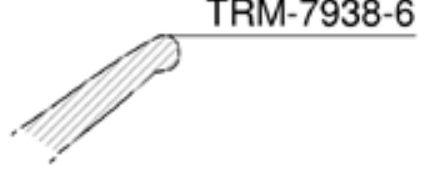

TRM-7938-7

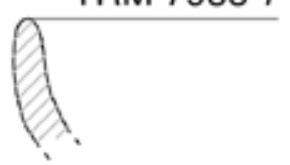

TRM-7939-7
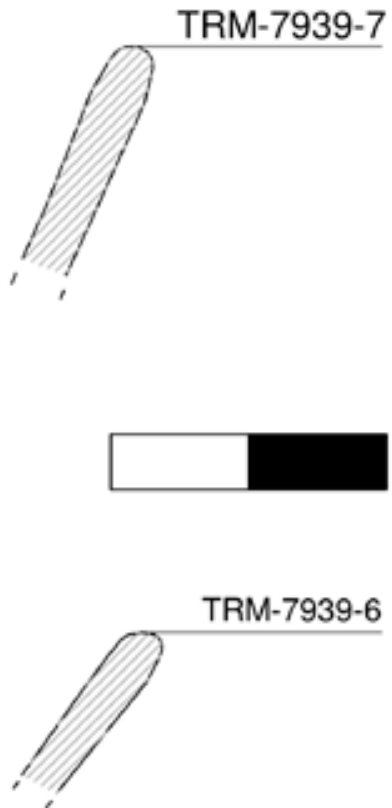

Figura 28 

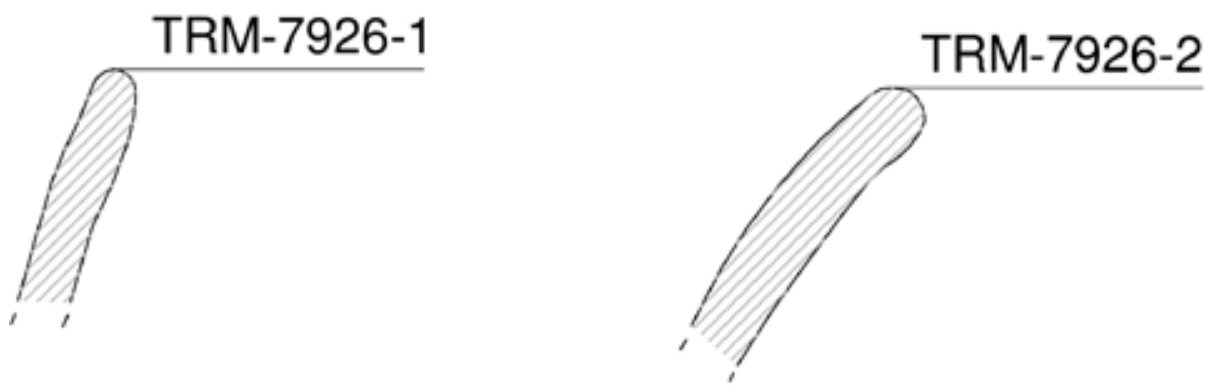

TRM-7927-2

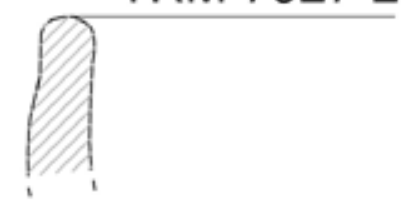

TRM-7927-3

TRM-7934-1
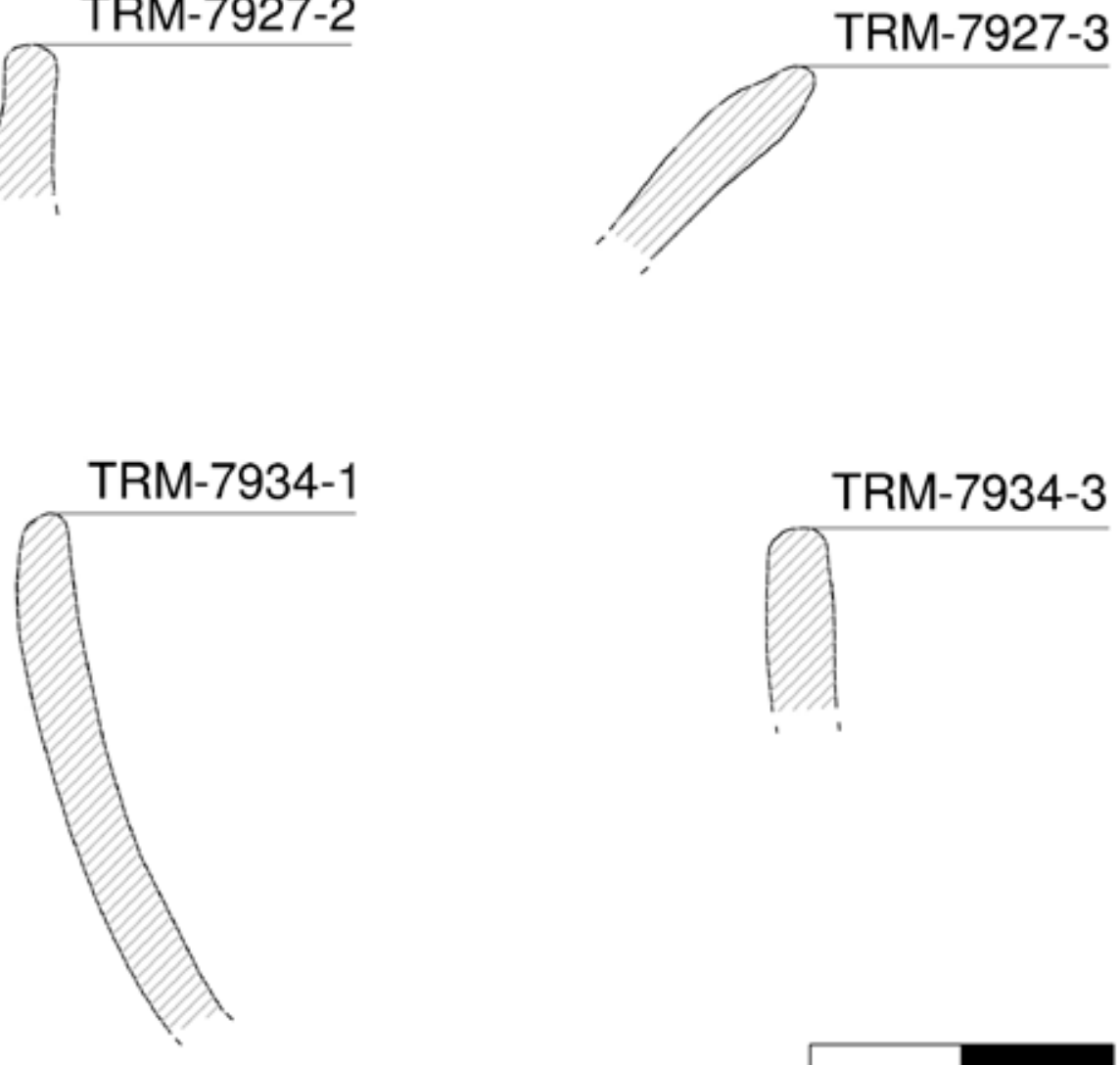

TRM-7934-3

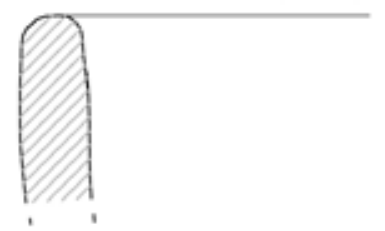

TRM-7930-4

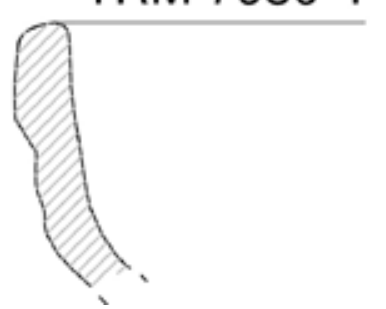

TRM-7940-2

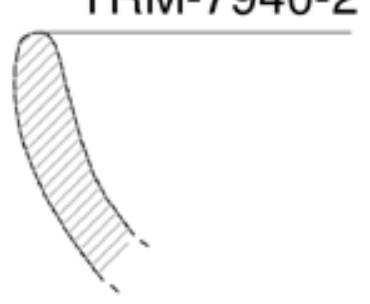

Figura 29 
TRM-7942-5

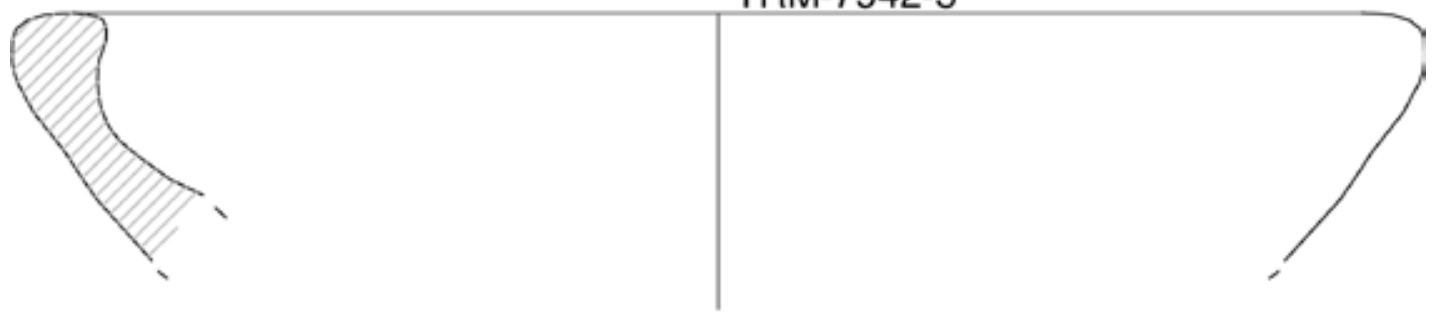

TRM-7942-1
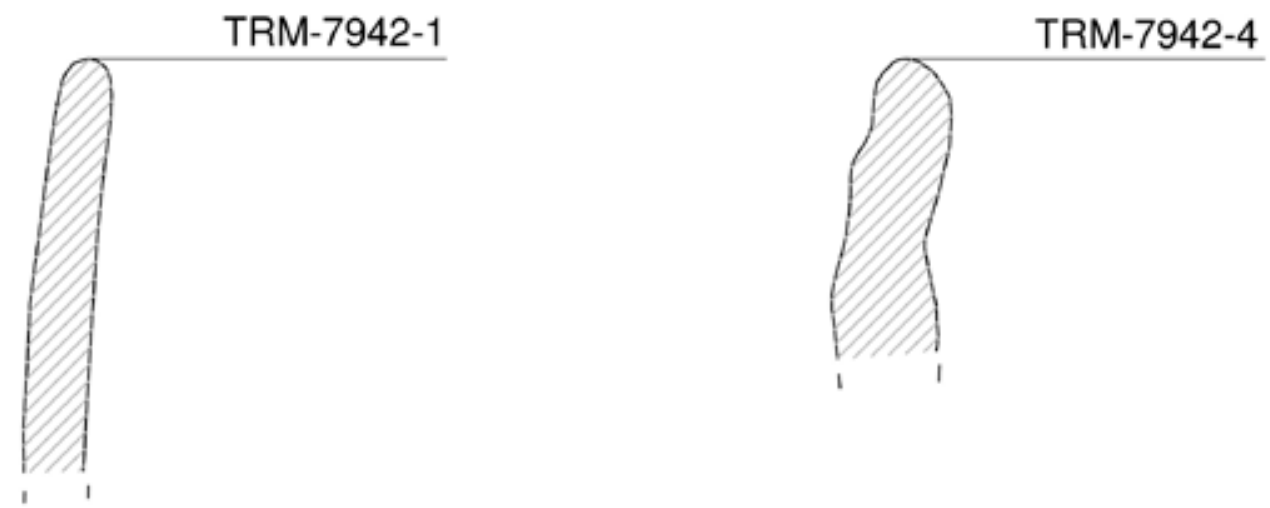

TRM-7942-2

TRM-7942-3
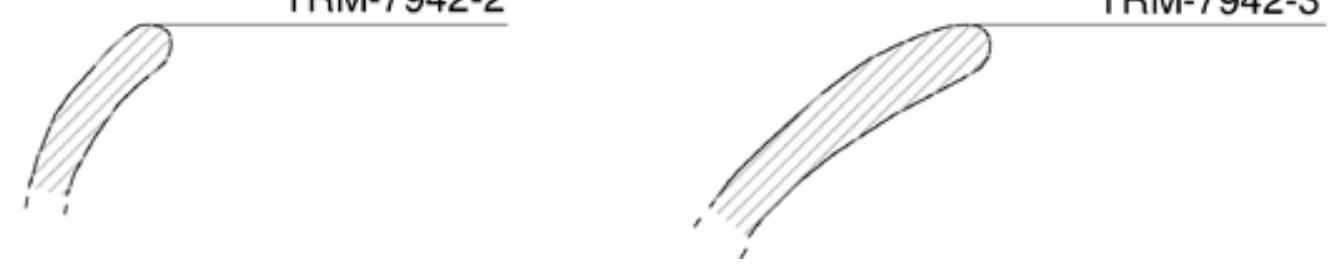

Figura 30
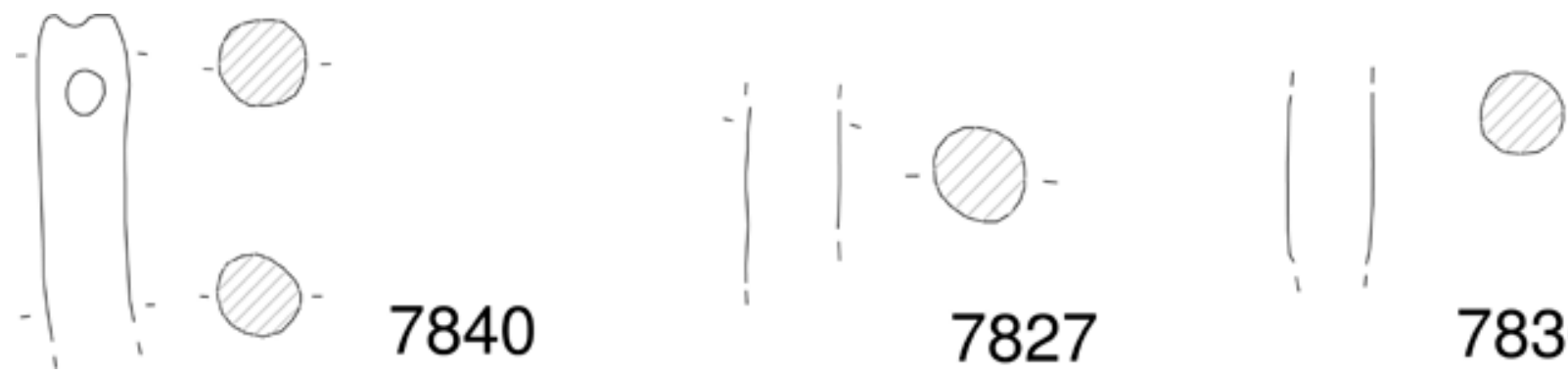

Figura 31 


\subsection{OtRos HALLAZGOS}

Los trabajos desarrollados de forma paralela a la ejecución del sondeo 'G' en la zona occidental del teatro, dejaron constancia de la existencia de materiales y restos calcolíticos que, aunque peor conservados, deben quedar incluidos en este trabajo, pues posiblemente, dada su proximidad a los restos anteriormente descritos, formen parte de un mismo contexto de ocupación.

Nos referimos a la existencia de un silo calcolítico, cuya presencia ya había sido mencionada en un trabajo anterior (Jiménez Ávila y Guerra Millán, 2012). Esta estructura, junto con otra serie de subestructuras o fosas de diversa cronología, había sido afectada por los trabajos arqueológicos llevados a cabo por Mariano del Amo en sus campañas arqueológicas de 1969 y 1970, pero no había llegado a ser excavada.

Se trata de una fosa (UE 3021) que conserva unas dimensiones máximas de 1,05 x 1,25 m y una profundidad de $0,65 \mathrm{~m}$, medida en su cara norte por ser la única que conserva todo su alzado. Mientras, su lado este ha quedado seccionado por la zanja de cimentación del muro perimetral del graderío del teatro romano y la parte oeste se ha visto afectada por la ejecución de un silo de cronología medieval. Por su parte, el fondo de la subestructura cortaba la roca de granito y presentaba una superficie bastante regular, aunque ligeramente rehundida en la parte central. Su acabado es algo irregular y en la parte superior de su extremo noreste parece presentar un cierto desarrollo hacia el interior que evidenciaría la existencia de una abertura o boca de menor tamaño (fig. 32).

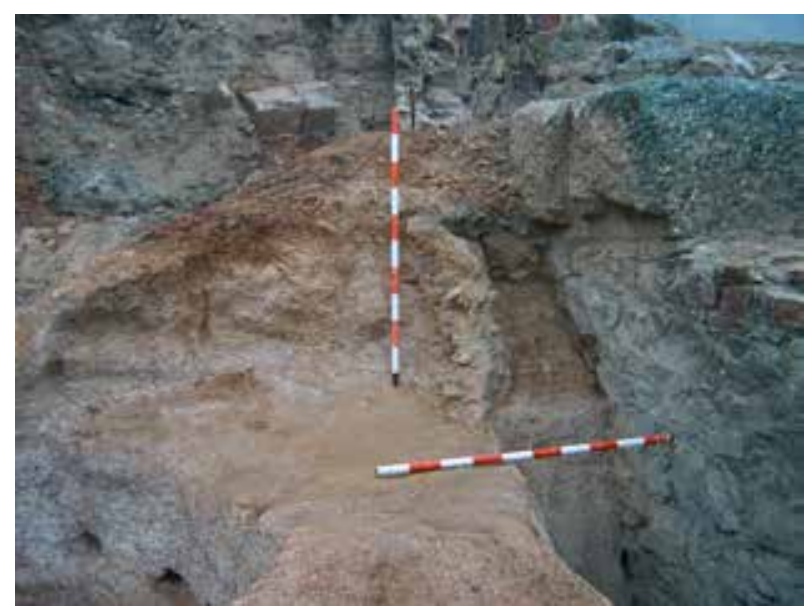

Figura 32
En cuanto al relleno del silo, se compone de un único estrato (UE 3020) formado por tierra compacta, de matriz arcillosa, con algunas raíces y restos de cuarcitas de mediado y pequeño tamaño. De este estrato pudo recuperarse un lote de materiales a partir de los cuales ha podido fecharse la estructura. Al igual que los restos documentos en el sondeo ' $G$ ', la cerámica hallada está fabricada en su totalidad a mano, con cocciones reductoras, de factura tosca pero con acabados alisados. Dentro del conjunto cabe destacar la presencia de un fragmento con decoración bruñida, dos fragmentos con carena, un borde de vaso de perfil hondo y un fragmento de plato de borde reforzado, sin duda el más significativo para fechar esta estructura (fig. 33).

\section{El CONTEXTO ARQueológico y El Poblamiento} CALCOLÍTICO DEL ENTORNO DE MEDELLÍN.

La documentación de varias estructuras y un conjunto de materiales calcolíticos en la ladera sur del cerro del Castillo de Medellín permite añadir un punto más en el mapa de poblamiento prehistórico del Guadiana Medio; un ejemplo más que sirve para ratificar el buen conocimiento que se posee de las pautas de poblamiento del entorno del río Guadiana durante el III milenio a.C. (Enríquez Navascués, 1990; 2003; Hurtado Pérez, 1995; Berrocal et alii, 2006, 67). La datación de los niveles aquí presentados se ha realizado a partir de las analogías detectadas, tanto en las estructuras excavadas como en las formas cerámicas con respecto a otros yacimientos repartidos por este amplio territorio, aprovechando la homogeneidad que caracteriza a los conjuntos materiales de época calcolítica (Enríquez Navascués, 2003, 82), pues carecemos de dataciones absolutas que permitan determinar una cronología más exacta. De ese modo, la uniformidad del repertorio, en el que destacan junto con los cuencos de casquete esférico y los vasos globulares, los platos de borde reforzado y borde almendrado, nos permite fechar la ocupación documentada entre el 3000 y el 2200 cal BC.

Las grandes construcciones levantadas en el cerro del Castillo de Medellín durante las etapas romana y medieval, no han permitido una buena conservación de los restos referentes a épocas anteriores. En esta ocasión, los cimientos de la construcción del teatro romano han arrasado buena parte de las estructuras correspondientes a la fase calcolítica. Sin embargo, a partir de los datos recogidos en este trabajo y de los fragmentos de cerámica calcolítica 


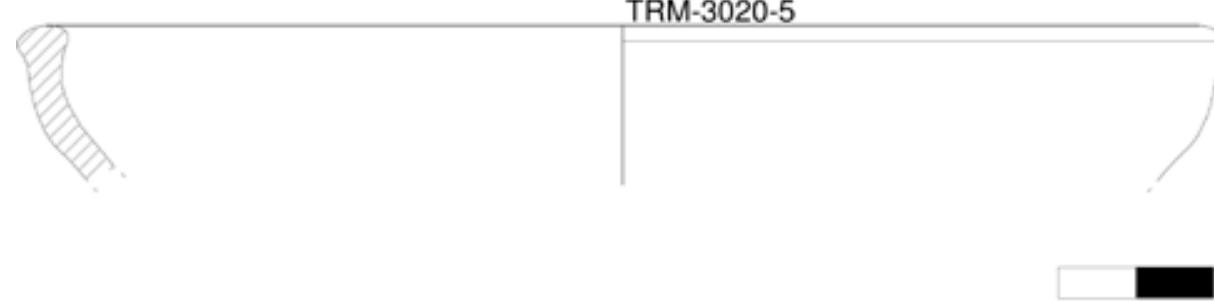

TRM-3020-2

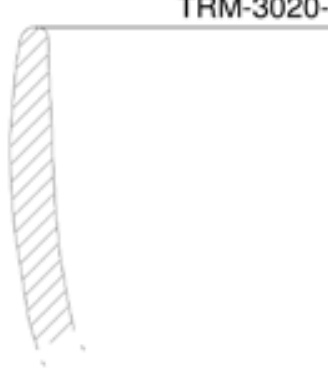

TRM-3020-1

TRM-3020-3

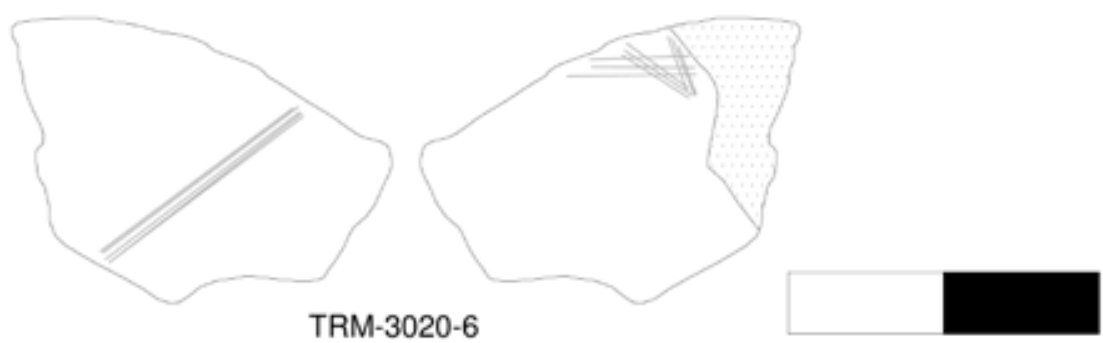

Figura 33

recuperados en el sondeo SMRO (Jiménez Ávila y Guerra Millán, 2012, 74), podemos concluir que la ocupación del cerro del Castillo de Medellín durante el III milenio a.C. parece restringirse a las laderas sur y oeste de la elevación, pues no existen evidencias de esta cronología en ninguno de los restantes trabajos llevados a cabo en distintas partes del cerro. No obstante, huelga decir que solamente el sondeo ' $G$ ' cuenta con niveles de ocupación correspondientes a época calcolítica, pues a pesar del lote de cerámicas recuperadas en el corte $\mathrm{SMRO}$, los autores encargados de su publicación aluden a la presencia de materiales pero a la ausencia de "paquetes estratigráficos bien definidos", por lo que la secuencia completa quedó fechada en el Bronce Final, aunque sin rechazar la posible existencia de una fase calcolítica en esta zona del cerro (Jiménez Ávila y Guerra Millán, 2012, 76).

Así mismo, cabría recordar la secuencia extraída de la denominada 'Cata Este del Teatro' (AlmagroGorbea, 1977), la cual por su proximidad espacial con los sondeos aquí presentados, puede que guarde con ellos alguna relación estratigráfica. En la descripción de la secuencia realizada en los años 70 del pasado siglo, se cita la existencia de un último nivel (XVI) localizado sobre la roca natural. Entre sus restos se describe la presencia de "un hogar relleno de finas cenizas y rodeado de adobes de arcilla amarillenta clara" (Almagro-Gorbea, 1977, 446), una descripción que bien se podría asemejar a la estructura excavada en el sondeo ' $G$ ' hoy aquí presentada. Dicha estructura fue fechada en el Bronce Final a partir de los materiales que contenía. Lamentablemente, no contamos con más datos que nos permitan vincular los hallazgos de la Cata Este del Teatro con las evidencias presentadas por nosotros, ni con los resultados obtenidos en los numerosos trabajos efectuados en la elevación, donde tampoco se ha tenido constancia de la existencia de una fase calcolítica que permita considerar que la ocupación estuvo diversificada por gran parte de la elevación (Rodríguez González, e.p.). 
Las evidencias constructivas con las que contamos para determinar el tamaño del enclave siguen siendo escasas como para trazar el perímetro definitivo de éste. Entre otros elementos de habitación, cabe suponer que un yacimiento de estas características estaría dotado de algún tipo de sistema defensivo, como ocurre en los yacimientos de La Palacina (Enríquez Navascués, 1990, 51) o Palacio Quemado (Hurtado Pérez y Enríquez Navascués, 1991), con los que la ocupación de Medellín guarda bastantes similitudes, tanto porque estos yacimientos ocupan espacios similares dentro del paisaje, como por las estructuras detectadas en los mismos.

Aunque limitados son también los datos de los que disponemos para definir la organización interna del asentamiento, los materiales y elementos constructivos documentados nos permiten esbozar una primera aproximación que podrá ser completada con los hallazgos futuros. A pesar de las reducidas dimensiones, se pudo documentar una estructura de combustión y sus diferentes niveles de uso. Posiblemente, dicha estructura tuviera un carácter doméstico, ya que no se han hallado restos de escorias propias de actividades artesanales en los niveles asociados, ni restos de una posible bóveda o del derrumbe de la misma que nos pudieran indicar que se trataba de un pequeño horno. Así mismo, y a pesar de que el ejemplo hallado en Medellín presenta una manufactura muy cuidada, las similitudes que guarda con el hogar excavado en el yacimiento de Palacio Quemado (Hurtado Pérez y Enríquez Navascués, 1991, 80-83) y la posible existencia de una cabaña al final de la secuencia (ocupación A), nos llevan a pensar en la presencia de un espacio doméstico en este punto. En cuanto al silo, y a pesar del grado de arrasamiento que presenta, existen ejemplos similares al documentado en Medellín, caso de las evidencias excavadas en las intervenciones del casco urbano de Mérida (Barrientos et alii, 1997), donde la aparición de varios silos ha sido puesta en relación con la explotación agrícola del entorno y el almacenaje del excedente. Así pues, nos encontramos frente a una nueva evidencia de hábitat localizada sobre una suave ladera que aprovecha tanto la estratégica ubicación del cerro, justo en un vado del Guadiana en la confluencia entre éste y el río Ortiga, como el control que la elevación tiene sobre tierras de alto potencial agrícola, de ahí que la ocupación de este enclave fuese fácilmente predecible.

La secuencia calcolítica extraída de las excavaciones de Cerro del Castillo de Medellín cierra una etapa más en el conocimiento de la ocupación de esta elevación, al mismo tiempo que suma un ejemplo más al mapa de poblamiento del valle medio del Guadiana durante el III milenio a.C. Así, dentro del excelente conocimiento que se tiene del poblamiento calcolítico de dicho valle, quizás las comarcas de Tierra de Barros y las Vegas Altas del Guadiana sean las mejor conocidas; la primera por albergar uno de los yacimientos más destacados de la Prehistoria reciente peninsular, La Pijotilla (Hurtado Pérez, 1995); el segundo por ser una de las regiones mejor conocidas desde el punto de vista arqueológico, como ya antes comentamos. No obstante, a pesar de que el número de enclaves documentados es elevado, el conocimiento derivado de ellos puede resultar muy limitado, pues la gran mayoría de las evidencias proceden de trabajos de prospección, de ahí que los restos hallados en Medellín estén cargados de interés, pues suman un nuevo ejemplo a la caracterización de las estructuras calcolíticas de esta región.

Si analizamos con detenimiento el mapa del poblamiento en el que se inserta el ejemplo de Medelín, podemos observar cómo el patrón de asentamiento que se detecta es bastante regular. Se trata de un territorio donde dominan los enclaves en áreas elevadas próximas a destacados cursos de agua (Berrocal et alii, 2006, 68). Pero entre la tipología de asentamientos documentados se detectan enclaves localizados tanto en llano, sin ninguna vocación estratégica pero con una fuerte vinculación a la tierra, como en ladera, cuya finalidad es controlar las tierras circundantes y las principales zonas de paso.

Sin embargo, el caso concreto de Medellín no responde a un modelo tan cerrado. El sistema de ocupación documentado en el cerro del Castillo parece estar a caballo entre dos de las categorías de asentamiento descritas en la introducción de este trabajo. A pesar de que el punto elegido para la ubicación del enclave es un cerro elevado junto a uno de los vados del Guadiana, la zona seleccionada para el establecimiento se localiza a mitad de camino de la ladera sur, la más suave de las cuatro que componen la elevación. Por esa razón, el enclave de Medellín forma parte del grupo de yacimientos que se sitúan sobre suaves lomas o pequeñas elevaciones junto al vado de un río, el más numeroso dentro del poblamiento del valle medio del Guadiana (Enríquez Navascués, 2003,78 ), con la salvedad de que este caso cuenta con un excepcional control visual sobre el entorno si se alcanza la cercana cima del cerro. 
En cuanto al poblamiento del entorno, destaca por la alta densidad de ocupaciones que aprovechan las excelentes tierras de cultivo que se extienden a lo largo de la cuenca del Guadiana. Sobre los enclaves localizados en llano, donde únicamente cabe destacar los ejemplos de Casa de las Puercas y La Habilla (Enríquez Navascués, 1990), sobresalen los yacimientos ubicados sobre suaves lomas. Entre ellos podemos citar los asentamientos de Rodriguillo, el Cerro del Castillo, Las Merchanas (Enríquez Navascués, 1990), Los Panchos y Patilla (Rodríguez Díaz et alii, 2009) o la Sierrecilla. Únicamente el último ejemplo de los citados ha sido objeto de excavaciones arqueológicas (Berrocal et alii, 2006), unos trabajos de los que se han extraído unos interesantes resultados al haberse documentado un pequeño enclave dedicado a la actividad metalúrgica. Esta actividad ha quedado evidenciada por la aparición de una vasija de reducción y varias lingoteras dentro de un espacio de hábitat (Berrocal et alii, 2006, 67) que destacan la existencia de un trabajo metalúrgico en un área alejada de las grandes explotaciones mineras. Así pues, las evidencias documentadas en el yacimiento de la Sierrecilla suman una actividad más a un territorio que siempre se ha vinculado con la actividad agrícola.

Hasta el momento, y a falta de evidencias que así lo certifiquen para el caso de Medellín, el poblamiento calcolítico de las Vegas Altas del Guadiana sigue sin contar con ejemplos de poblados fortificados, un hecho que contrasta con los numerosos casos registrados en la zona de Tierra de Barros (Hurtado Pérez, 1995, 60-61). Los dos ejemplos más cercanos a nuestro caso de estudio lo constituyen los asentamientos de Palacio Quemado (Hurtado Pérez y Enríquez Navascués, 1991) anteriormente citado, y el yacimiento de La Palacina (Enríquez Navascués, 1990, 166-ss), ambos localizados en el término municipal de Alange, a caballo entre las comarcas naturales de Tierra de Barros y las Vegas Altas del Guadiana. Su ubicación ha sido el argumento empleado para defender la existencia de murallas en ambos casos, pues su localización en un punto de frontera les infiere un importante papel como controladores de territorio.

En definitiva, el conjunto de materiales y las estructuras aquí presentadas constituyen la primera evidencia de una fase de ocupación calcolítica en el cerro del Castillo de Medellín. Ésta se localiza concretamente en la ladera sur de la elevación, donde la posterior ocupación durante época romana y me- dieval es destacable. Por esa razón no podemos dudar de la importancia geográfica y estratégica que debió de desempeñar esta elevación en el pasado. Su continuada ocupación desde la Prehistoria Reciente hasta época moderna (Guerra Millán et alii, 2014) es un argumento más que válido para corroborar el papel que debió de desempeñar como controlador del paisaje. Solo la continuidad de los trabajos en torno al Teatro Romano de Medellín nos permitirá acercarnos un poco más al conocimiento del III milenio en este destacado espacio geográfico.

\section{AgRADECIMIENTOS}

Nuestro agradecimiento a la Mancomunidad Integral de Municipios del Guadiana y a la Dirección General Patrimonio Cultural de la Junta de Extremadura, porque fueron las dos administraciones que tutelaron el desarrollo de las excavaciones arqueológicas aquí referidas y que nos han permitido utilizar parte de la documentación gráfica que se presenta en este trabajo. También agradecemos a Samuel Pérez Romero su colaboración en la edición del plano de localización de vestigios calcolíticos presentado en este trabajo y a Luis Lechón la realización del vuelo en avioneta con el que se realizaron las fotos aéreas del yacimiento. Así mismo, manifestamos nuestra gratitud a los Drs. Enrique Cerrillo y Víctor Hurtado, quienes accedieron a revisar el material que aquí presentamos.

\section{Bibliografía}

Almagro-Gorbea, M. (1977), El Bronce Final y el Periodo Orientalizante en Extremadura, Bibliotheca Praehistorica Hispana, Madrid.

Barrientos Vera, T., Jiménez Ávila, J. y Montalvo Frías, A. (1997), "Nuevos hallazgos prehistóricos en el casco urbano de Mérida", Mérida, excavaciones Arqueológicas. Memoria 3, Mérida, 265-299.

Berrocal, Ma . C., Cerrillo Cuenca, E. y García Solano, J. A. (2006), "Nuevos datos sobre el Calcolítico de Extremadura: el yacimiento de la Sierrecilla (Santa Amalia, Badajoz)”, Spal, 15, 51-70.

Enríquez Navascués, J. J. (1990), El Calcolítico o Edad del Cobre de la cuenca extremeña del Guadiana: los poblados, Badajoz.

Enríquez Navascués, J. J. (1995), "Del Paleolítico a la Edad del Bronce", Extremadura Arqueológica, 4, 13-34.

Enríquez Navascués, J. J. (2003), Prehistoria de Mérida. Cazadores, campesinos, jefes, aris- 
tócratas y siervos anteriores a los romanos), Cuadernos emeritenses, 23, Mérida.

Guerra Millán, S.; Collado Giraldo, H. y Pérez Romero, S. (2014), "Metellinum, síntesis histórica y novedades arqueológicas de esta ciudad romana”, Ciudades Romanas de Extremadura. Stvdia Lusitana 8 (Nogales, T. y Pérez del Castillo, M. J. Eds.), Mérida, 195-221.

Heras Mora, F. J. y Cerrillo Cuenca, E. (2006), "Paisaje y dinámica cultural de la Prehistoria Reciente en el Guadiana Medio", IV Congresso de Arqueología Peninsular. De Epipaleolitico ao Calcolítico na Península Ibérica, Faro, 279-291.

Hurtado Pérez, V. (1995), “Interpretación sobre la dinámica cultural en la Cuenca Media del Guadiana (IV-III milenio a.n.e.)", Extremadura Arqueológica, 5, 53-80.

Hurtado Pérez, V. y Enríquez Navascués, J. J. (1991), "Excavaciones en la Palacio Quemado (Alange, Badajoz). Informe preliminar”, Extremadura Arqueológica, II, 69-87.

Jiménez Ávila, J. y Guerra Millán, S. (2012), “El Bronce Final en Medellín. Estudio preliminar del Corte SMRO", Sidereum Ana II. El río Guadiana en el Bronce Final. Anejos del Archivo Español de Arqueología LXII (Jiménez Ávila, J. Ed.), Mérida, 65-110.

Rodríguez Díaz, A y Enríquez Navascués, J. J. (2001), Extremadura tartésica. Arqueología de un proceso periférico, Barcelona.

Rodríguez Díaz, A., Pavón Soldevila, I. y Duque Espino, D. (2009), "Contexto territorial e histórico”, El caserío de Cerro Manzanillo (Villar de Rena, Badajoz) y la colonización agraria orientalizante en el Guadiana Medio. Memorias de Arqueología Extremeña 12 (Rodríguez Díaz, A., Duque, D. y Pavón, I., Eds.), Cáceres, 183-322.

Rodríguez González, E. (e.p.), El poblamiento del valle medio del Guadiana durante la I Edad del Hierro, Bibliotheca Praehistorica Hispana, Madrid.

Sevillano Perea, L., Mayoral Herrera, V., Salas Tovar, E., Liceras Garrido, R. y Heras Mora, F. J. (2013), "Detectando prácticas agrarias antiguos en el territorio sur de Medellín. La expresión material de las actividades agrícolas protohistóricas del Suroeste peninsular", Actas del VI
Encuentro de Arqueología del Suroeste peninsular (Jiménez Ávila, J., Bustamante, M. y García, M., Eds.), 1032-1063. 